\title{
Mechanistic Understanding of Curcumin's Therapeutic Effects in Lung Cancer
}

\author{
Wan Nur Baitty Wan Mohd Tajuddin ${ }^{1}$, Nordin H. Lajis ${ }^{2}$, Faridah Abas ${ }^{2,3}$, Iekhsan Othman ${ }^{1}$ (D) \\ and Rakesh Naidu ${ }^{1, *}$ \\ 1 Jeffrey Cheah School of Medicine and Health Sciences, Monash University Malaysia, Jalan Lagoon Selatan, \\ Bandar Sunway, Selangor Darul Ehsan 47500, Malaysia; \\ wan.wanmohdtajuddin@monash.edu (W.N.B.W.M.T.); iekhsan.othman@monash.edu (I.O.) \\ 2 Laboratory of Natural Products, Faculty of Science, Universiti Putra Malaysia, UPM, Serdang 43400, \\ Malaysia; nordinlajis@gmail.com (N.H.L.); faridah@food.upm.edu.my (F.A.) \\ 3 Department of Food Science, Faculty of Food Science and Technology, Universiti Putra Malaysia, UPM, \\ Serdang 43400, Malaysia \\ * Correspondence: kdrakeshna@hotmail.com; Tel.: +60-3-5514-6345
}

Received: 15 October 2019; Accepted: 30 November 2019; Published: 6 December 2019

\begin{abstract}
Lung cancer is among the most common cancers with a high mortality rate worldwide. Despite the significant advances in diagnostic and therapeutic approaches, lung cancer prognoses and survival rates remain poor due to late diagnosis, drug resistance, and adverse effects. Therefore, new intervention therapies, such as the use of natural compounds with decreased toxicities, have been considered in lung cancer therapy. Curcumin, a natural occurring polyphenol derived from turmeric (Curcuma longa) has been studied extensively in recent years for its therapeutic effects. It has been shown that curcumin demonstrates anti-cancer effects in lung cancer through various mechanisms, including inhibition of cell proliferation, invasion, and metastasis, induction of apoptosis, epigenetic alterations, and regulation of microRNA expression. Several in vitro and in vivo studies have shown that these mechanisms are modulated by multiple molecular targets such as STAT3, EGFR, FOXO3a, TGF- $\beta$, eIF2 $\alpha$, COX-2, Bcl-2, PI3KAkt/mTOR, ROS, Fas/FasL, Cdc42, E-cadherin, MMPs, and adiponectin. In addition, limitations, strategies to overcome curcumin bioavailability, and potential side effects as well as clinical trials were also reviewed.
\end{abstract}

Keywords: lung cancer; curcumin; anti-cancer; molecular mechanism

\section{Introduction}

Lung cancer is a highly malignant tumor and one of the most common types of cancer worldwide. In 2012, it was estimated that 1.8 million new lung cancer cases represent approximately $12.9 \%$ of all cancers diagnosed worldwide [1]. According to the estimation of The International Agency for Research on Cancer (IARC), there was 2.1 million new lung cancer cases and the number of lung cancer-associated death rose to 1.8 million worldwide in 2018 [2].

Lung cancer is classified into two types which include non-small cell lung cancer (NSCLC) and small cell lung cancer (SCLC) that account for approximately $80 \%$ and $20 \%$ of all lung cancer cases respectively [3]. Due to the limitations of effective screening and asymptomatic clinical manifestation at early stage of disease, $70 \%-80 \%$ lung cancer patients were diagnosed at an advanced stage [4]. To date, the standard treatments for the majority of lung cancer patients including SCLC and NSCLC are surgery, chemotherapy, radiation therapy, or a combination of these treatments [5]. In addition, targeted therapy drugs such as tyrosine kinase inhibitors (TKIs) of epidermal growth factor receptor (EGFR) and anaplastic lymphoma kinase (ALK) are used to treat NSCLC patients [6]. In recent 
years, immunotherapy drugs have been introduced to treat some patients of NSCLC by targeting the programmed cell death receptor on T cells [7]. Unfortunately, all of the standard treatments, targeted therapy, and immunotherapy drugs have been reported to cause several side effects and toxicities in lung cancer patients $[5,8,9]$. Furthermore, the prognosis of lung cancer remains poor as the five-year survival rate for all stages combined is approximately $16 \%$ despite the significant advances in diagnostic and therapeutic approaches [10]. It has been indicated that poor prognosis is associated with late diagnosis, drug resistance, and toxicity [11]. Therefore, further investigations and research on lung cancer mechanisms, non-toxic therapeutics drugs, and new intervention targets are significant as the understanding in this context would prove useful in lung cancer therapy.

More than 35,000 plants species including spices and herbs are being consumed extensively around the world as they are believed to have numerous therapeutic properties with reduced side effects [12]. Among these species, curcuma longa (also known as turmeric) has been used widely since ancient times as a spice in traditional cuisine as well as a traditional medicine in Southeast Asia, India, and China [13]. Curcumin which is the main component of turmeric has been shown to have numerous therapeutic activities including anti-inflammatory [14], anti-oxidant [15], anti-microbial [16], anti-atherosclerosis [17,18] and anti-cancer [19]. Multiple studies have revealed that curcumin may act as a potential chemopreventive agent as well as a novel adjuvant treatment for cancer [20]. In addition, clinical trials have proven curcumin is a safe and well tolerated dietary constituent for humans, and with anti-carcinogenic capability [21]. Several studies in vitro and in vivo showed curcumin demonstrates anti-cancer effects on lung cancer through mechanisms such as inhibition of cell proliferation, induction of apoptosis, epigenetics changes, and regulation of microRNAs expression [20]. In this current review, modulation of multiple molecular targets and signaling pathways including STAT3, EGFR, FOXO3a, TGF- $\beta$, eIF2 $\alpha$, COX-2, Bcl-2, PI3KAkt/mTOR, ROS, Fas/FasL, Cdc42, E-cadherin, MMPs, and adiponectin were discussed. In addition, strategies to overcome curcumin bioavailability, limitations, and potential side effects, as well as clinical trials were also reviewed.

\section{Mechanism of Anti-Cancer Effect on Lung Cancer}

\subsection{Effects of Cell Proliferation and Cell Cycle}

Cell proliferation results in increased number of cells and highly regulated in normal cells. It is defined by coordinated cell cycle that creates the balance between cell division and cell loss. Therefore, dysregulation of the cell cycle can cause excessive or uncontrolled proliferation, contributing to the development of malignant tumor cells [22,23]. A number of studies have documented curcumin mediated anti-proliferative effect in lung cancer cells via modulation of various molecular targets such as STAT-3, EGFR, Forkhead Box O3 (FOXO3a), Eukaryotic Initiation Factors (eIFs), and Transforming Growth Factor-Beta (TGF- $\beta$ ).

\subsubsection{Signal Transducer and Activator of Transcription 3 (STAT3)}

STAT3 protein is a member of the STAT protein family that serves as a transcription factor transmitting signals from the cell surface to the nucleus [24]. STAT3 is activated through STAT3 tyrosine phosphorylation by Janus Kinase (JAK) and growth factor receptor tyrosine kinase in response to the bonds of cell surface receptors to ligands such as epidermal growth factor (EGF), interferons and interleukin-6 (IL-6) $[25,26]$. Activation of STAT3 is a feature in normal human cells as it involves in regulation of multiple cellular functions such as cell proliferation, differentiation, host defense, and development [27]. While activated STAT3 protein in normal cells is well controlled and has a short lifespan, the activated STAT3 protein in cancer cells including lung cancer is continuously active leading to uncontrolled proliferation, apoptosis resistance, as well as sustained angiogenesis [28-30]. It has been reported that activated STAT3 protein is expressed in over $50 \%$ of NSCLC primary tumors and cell lines [31-33] while 100\% of SCLC tumor tissues tested contain high level of activated STAT3 protein [34]. Persistent activation of STAT3 protein has been correlated with enhanced cell proliferation 
in both NSCLC through its ability to induce the expression of several growth-promoting genes such as c-myc, Pim-1, and cyclin D1 [35-37].

Recently, researchers found that suppression of STAT3 phosphorylation has contributed to anti-proliferative effect of curcumin against both SCLC and NSCLC. Yang et al. (2012) revealed that curcumin inhibits the STAT3 phosphyorylation in SCLCNCI-H446 and NCI-1688 which in turn causes downregulation of cyclin B1, a key component in the control of cell cycle progression from G2 to M phase. Thus, this activity subsequently arrests the G2 phase of cell cycle and inhibits the cell proliferation. In addition, this study also showed that the inhibition of STAT3 phosphorylation by curcumin is able to cause loss of colony formation, and the inhibit migration and invasion of cancer cells [38]. Similarly, Wu (2015) showed that curcumin inhibited the JAK2/STAT3 signaling pathway in NSCLC NCI-H460 cells, which resulted in downregulation of cyclin D1 and c-myc that serve as regulators of cell cycle progression and transcriptional factor respectively. Consequently, it leads to the inhibition of cell proliferation and colony formation in NCI-H460 lung cancer cells. Curcumin could also reduce tumor spheres of NCI-H460 cells by inhibiting the JAK2/STAT3 signaling pathway in both in vitro as well as in vivo [39]. The anti-proliferative effect of curcumin on lung cancer cells via the STAT3 phosphorylation pathway has been further confirmed in both in vitro and in vivo studies by Alexandrow et al. (2012). It was indicated that human lung adenocarcinoma H441 cells are sensitive to curcumin exposure in a dose-dependent manner resulting in a reduction of cell proliferation. In agreement with this, the results also showed that curcumin suppresses STAT3 phosphorylation activity and further inhibits expression of cyclin D1 and mcm 2 markers indicating a reduced proliferative ability [40]. In a recent study, Tang et al. (2018) demonstrated that curcumin may act as a STAT3 inhibitor to inhibit proliferation in lung squamous cell carcinoma NCI-H292. The results revealed that inhibition of STAT3 increased Forkhead box transcription factor A2 (FOXA2) expression, and it has been reported that overexpression of FOXA2 reduced cell growth, inhibited cell proliferation, and induced apoptosis as it functions in regulating the expression of genes critical to lung morphogenesis [41]. Taken together, the above findings suggest that the anti-proliferative effect of curcumin via the STAT3 signaling pathway could be a potential target for lung cancer chemotherapeutic therapy.

\subsubsection{Epidermal Growth Factor Receptor (EGFR)}

EGFR also known as HER-1 or ERbB1 belongs to the family of growth factor receptor tyrosine kinases (TKs). It has been described previously that EGFR-TKs are involved in fundamental cellular functions such as cell proliferation, division, and differentiation [42,43]. The activation of EGFR results in activation of Raf/MEK/Erk, STAT, and P13k/AKT pathways which lead to cell survival [44-46]. Multiple evidence suggests that aberrant EGFR expression and signaling contribute to tumorigenesis as well as progression of various cancer types including lung cancer [47-49]. Elevated expression of EGFR is found in $62 \%$ of NSCLC and it is associated with poor prognosis as well as reduced survival rate in lung cancer patients [50-52]. It has been demonstrated that curcumin downregulates EGFR in multiple cancer cells including NSCLC and subsequently inhibits its cell proliferation. A study by Jiang and co-investigators (2014) revealed that curcumin downregulated EGFR in A549 lung cancer cells and increased expression of UBE1L. UBE1L has been regarded as a potential tumor suppressor gene and decreases overall levels of cyclin D1. Hence, this promotes the suppression of cell growth [53].

\subsubsection{Forkhead Box O3 (FOXO3a)}

FOXO3a belongs to a family of the Forkhead box class O (FOXO) transcription factor which plays a crucial role in cellular functions such as cell cycle arrest, apoptosis, DNA damage repair, and differentiation, as well as stress detoxification [54,55]. Several studies demonstrated that a reduced level of FOXO3a expression contributes to cell transformation, tumor progression, and angiogenesis in a variety of cancer cells including lung cancer [56-58]. Several studies have reported that curcumin mediates anti-cancer effect in cancer cells including neuroblastoma and lung cancer through modulation 
of FOXO3a expression. It has been demonstrated that curcumin and its analogues increase the expression of FOXO3a in A549 and H460 human lung cancer cells through enhancement of ROS production, subsequently elevating the expression of FOXO3a target genes including $p 21, p 27$ and Bim while decreasing the level of cyclin D1. Of note, both inhibitor protein p21 and p27 suppresses G1 to $S$ cell cycle transition, followed by cell proliferation inhibition of A549 and H460 cells. In addition, this study also showed that curcumin suppresses the growth of A549 lung cancer xenograft tumors associated with suppression of proliferation in tumor tissues [59].

\subsubsection{Transforming Growth Factor Beta (TGF- $\beta$ )}

Transforming growth factor- $\beta$ belongs to a family of three multifunctional cytokines that plays an important role in the regulation of cell proliferation as well as differentiation in most human epithelial tissues [60]. TGF- $\beta$ signaling regulates several cellular functions such as cell growth, differentiation, angiogenesis, apoptosis, and extracellular matrix remodeling [61]. Deregulation of TGF- $\beta$ expression has been associated with tumor development and progression depending on tumor types and stages [62]. Previous studies have demonstrated that TGF- $\beta$ exhibits anti-tumor roles in NSCLC through the smad pathway. Consequently, it activates TGF- $\beta$ responsive gene expression, suppresses cell proliferation, induces apoptosis as well as reduces tumorigenicity [63-65]. Curcumin has been reported to regulate TGF- $\beta$ signaling cascade in neonatal lung fibroblast [66], renal cells [67], keloid fibroblasts [68], and scleroderma fibroblasts [69]. Interestingly, Datta and colleagues (2013) revealed that the anti-cancer effect of curcumin on NSCLC cells in vitro and in vivo on mouse tumor xenograft was linked irrespectively to the TGF- $\beta /$ Smad signaling pathway. The findings showed that curcumin has no significant effect on both TGF- $\beta$ sensitive and TGF- $\beta$ insensitive NSCLC cell lines. Hence, it can be suggested that curcumin could be a potential anti-cancer agent for both TGF- $\beta$ sensitive as well as TGF- $\beta$ resistant NSCLC tumors [70].

\subsubsection{Eukaryotic Initiation Factors 2 Alpha (eIF2 $\alpha)$}

The eIF $2 \alpha$ is a regulatory subunit of eIF $2 \alpha$ which plays a pivotal role to initiate translation of protein synthesis process in eukaryotic cells. Notably, phosphorylation of eIF2 $\alpha$ results in inactivation of the whole eIF2 and reduces the level of active eIF2 $\alpha$ inhibiting global protein synthesis [71]. Previous studies have revealed that a higher level of eIF $2 \alpha$ has been observed in oncogene transformed cells and tumor cells such as Hodgkin's lymphoma [72], esophageal cancer [73], gastrointestinal carcinomas [74], and malignant melanoma [75], as well as bronchioloalveolar carcinomas of the lung [76]. Increased expression of eIF2 $\alpha$ leads to increased protein synthesis, which is associated with tumorigenesis. Chen and co-investigators demonstrated that curcumin inhibits cell proliferation as well as cell viability of A549 lung adenocarcinoma cells through modulation of eIF2 $\alpha$ expression. Curcumin decreases the expression of eIF $2 \alpha$ and increases the phosphorylation of eIF $2 \alpha$ which inhibits initiation of translation and inhibition of protein synthesis, thus suppressing cell proliferation [77].

The above findings indicate that the anti-proliferative effects of curcumin against lung cancer are associated with the modulation of transcription factors, protein kinases, and cell cycle regulatory proteins as presented in Figure 1. 


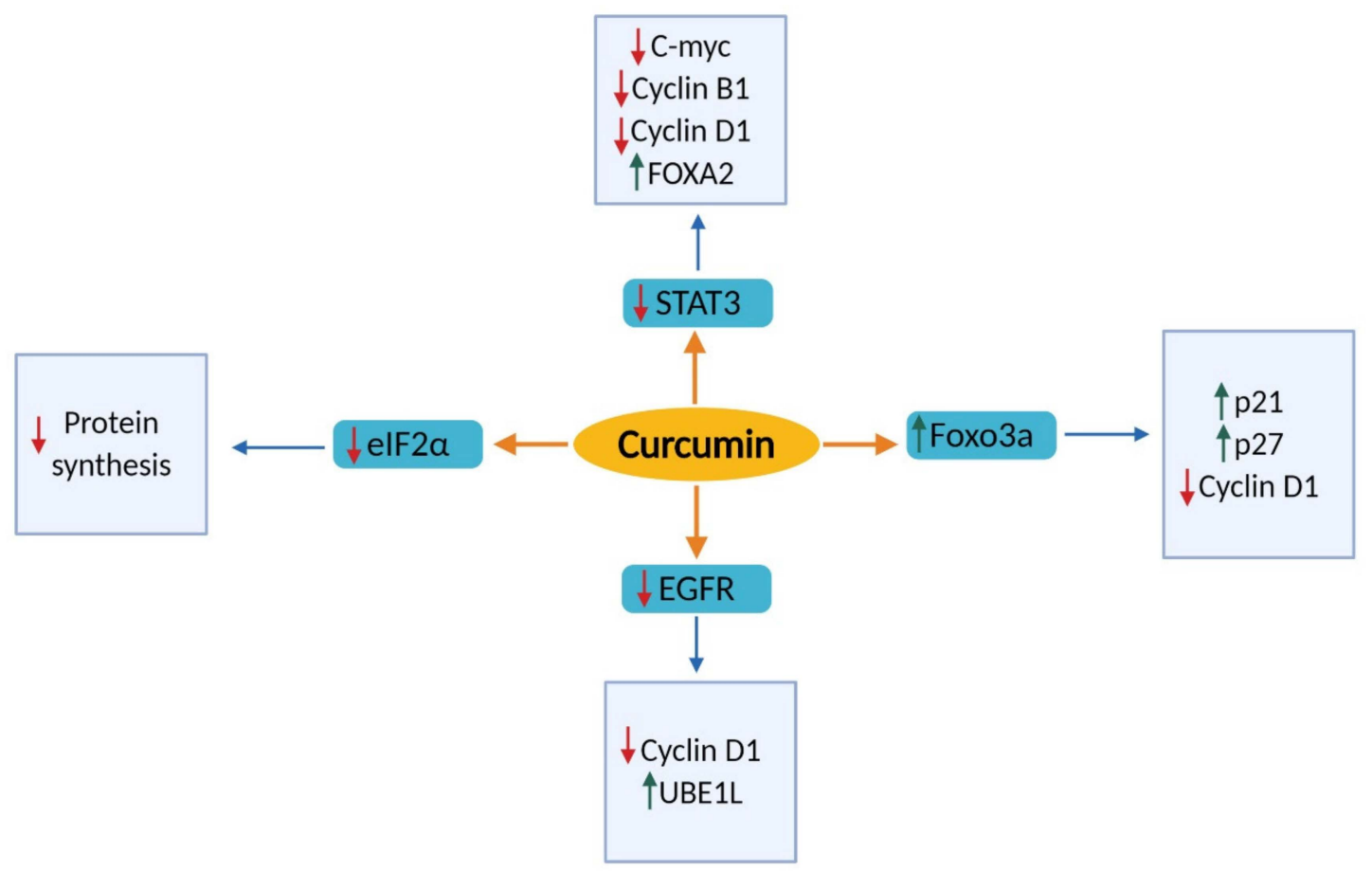

Figure 1. Molecular targets of curcumin in inhibiting cell proliferation of lung cancer cells. The green arrow indicates upregulation, while the red arrow indicates downregulation of molecular targets. STAT 3: Signal transducer and activator of Transcription 3; eIF2 $\alpha$ : Eukaryotic initiation factors 2 alpha; EGFR: Epidermal growth factor receptor; Foxo3a: Forkhead box class O; FOXA2; Forkhead box transcription factor A2; UBE1l: Ubiquitin-like modifier-activating enzyme; C-myc: C-myc proto-oncogene.

\subsection{Effects on Apoptosis}

Apoptosis or programmed cell death, has been known as an essential and highly regulated event in cell homeostasis and eukaryotic development. Deregulation in apoptotic process can result in the tumor cell formation as it creates a permissive environment for genetic pathway instability and the accumulation of mutations [78]. Thus, making the molecular pathways of apoptosis as the most potent targets to counter the cancerous growth. Curcumin has been shown to induce apoptosis in lung cancer cells via both intrinsic and extrinsic pathways by regulating multiple molecular targets including Cyclooxygenase 2 (COX-2), Bcl-2 family, reactive oxygen species (ROS), death receptors, and signaling pathways such as Phosphatidylinositol-3-kinase (PI3K).

\subsubsection{Cyclooxygenase 2 (COX-2)}

Cyclooxygenase also referred as prostaglandin H synthase-2 or PTGS2 is an enzyme that responsible for the production of postanoids including prostaglandins and thromboxanes from free arachidonic acid [79]. Accumulating evidences have shown frequent upregulation of COX-2 expression in both pre-malignant and malignant tissues including lung cancer, suggesting that COX-2 is one of the key factors in carcinogenesis [80-85]. The elevated expression of COX-2 was found to impact multiple pathways involved in malignant progression such as resistance to apoptosis, promotion of angiogenesis, increased proliferation, as well as increased malignancy [86-88]. Higher expression of COX-2 level has been observed in at least $70 \%$ of lung adenocarcinomas and squamous cell carcinomas compared to the adjacent normal lung tissue [89]. It has been shown that inhibition of COX-2 able to induce apoptosis in COX-2 overexpressing lung cancer cells [90].

Curcumin has been revealed to serve as a potential COX-2 inhibitor in multiple types of cancer including lung cancer, for its ability to suppress COX-2 expression. In a study with NSCLC P14 cells, curcumin downregulates COX-2 and EGFR expressions. This study showed that the COX-2 product, prostaglandin $\mathrm{E}_{2}\left(\mathrm{PGE}_{2}\right)$, is able to transactivate the EGFR pathway through four $\mathrm{G}$ protein-coupled 
receptors (GPCRs), resulting in the promotion of cancer cell growth and motility. The cross-talk between the EGFR signaling and COX-2 pathways was associated with a decreased extra-cellular signal regulated kinase (ERK1/2) activity which resulted in the inhibition of cell survival and induction of apoptosis [91]. In addition, curcumin on COX-2 downregulation is mediated through NF-kB. Curcumin has been shown to inhibit activation of NF- $\mathrm{KB}$ that suppresses IKK which inhibits phosphorylation and degradation of IkB-kinase alpha (IkBa) followed by p65 nuclear translocation [92]. A study by Charalambous and co-workers found that upregulation of COX-2 was accompanied by elevated expression of NF-kB-p65 and IkBa in human colorectal cancer epithelial cells [93]. Similarly, as reported in a recent study on NSCLC H1975 cells, curcumin inhibits COX-2 expression through modulation of NF- $\mathrm{kB}, \mathrm{IkBa}$ and $\mathrm{p} 65$ expression which in turn increased induction of apoptosis and reduced survival of the NSCLC cells. Furthermore, in vivo experiments also demonstrated that curcumin caused $36 \%$ reduction in weight of intra lung tumors and downregulation of COX-2 expression [94].

\subsubsection{B-cell Lymphoma-2 (Bcl-2) Family Member}

Bcl-2 family proteins are key regulators of apoptosis through mitochondrial apoptotic pathways by promoting caspase cascade activation [95]. Bcl-2 family members are classified into two groups which include anti-apoptotic proteins $\left(\mathrm{Bcl}-2, \mathrm{Bcl}-\mathrm{X}_{\mathrm{L}}, \mathrm{Bcl}-\mathrm{W}\right)$ and pro-apoptotic proteins (Bax, Bak, Bcl-Xs, Bad, Bid) [96]. The balanced ratio of various Bcl-2 family members play a vital role in cellular apoptotic homeostasis. It has been reported that, elevated expression of Bcl-2 has been observed in numerous types of cancer including lung cancer [97]. Bcl-2 overexpression was found in $19 \%-33 \%$ of NSCLC cases [98-100], while up to 90\% of SCLC cases [101,102]. The overexpression of Bcl-2 in lung cancer cases has been linked to poor prognosis as well as cell survival.

Wu and co-workers (2010) reported that curcumin treatment downregulates Bcl-2 and Bcl-XL but upregulates Bax and Bad proteins in NSCLC NCI-H460 cells. The ratio between pro- and anti-apoptotic Bcl-2 family members on mitochondrial membranes was displaced leading to increased membrane permeability followed by leakage of cytochrome $C$ into the cytosol [103]. Consequently, these changes caused activation of caspase cascade and induced apoptosis [104,105]. Similarly, curcumin induced apoptosis in NSCLC A549 cells through the regulation of Bcl-2/Bax protein that affects the mitochondrial apoptotic pathway $[106,107]$. In addition, another study has revealed that curcumin induced apoptosis in NSCLC cells by continuous elevation of $\mathrm{Ca}^{2+}$ that was caused by downregulation of Bcl-2 protein [108]. It has been reported that $\mathrm{Bcl}-2$ suppression plays an important role in the regulation of calcium release from endoplasmic reticulum (ER) through IP3R phosphorylation. Bcl-2 acts as a docking protein to facilitate the interaction of IP3R and calcineurin, which then dephosphorylates IP3R, decreasing the channel activity [109]. Excessive accumulation of $\mathrm{Ca}^{2+}$ in the cytoplasm leads to the opening of mitochondrial permeability transition pore ( $\mathrm{mPTP}$ ) as well as enhances mitochondrial outer membrane permeabilization (MOMP) followed by releasing cytochrome $C$ into the cytosol [110]. These findings suggest that the downregulation of Bcl-2 by curcumin in NSCLC cells is associated with calcium overload which contributes to mitochondrial-dependent apoptosis.

\subsubsection{Phosphatidylinositol-3-kinase-Akt-mTOR (PI3K/Akt/mTOR)}

Phosphatidylinositol-3-kinase (PI3K), a lipid kinase family, is activated by the binding of extracellular growth factors to transmembrane receptor tyrosine kinases (RTKs) such as the vascular endothelial growth factor receptor (VEGFR), EGFR, insulin-like growth factor 1 receptor (IGF-1R), fibroblast growth factor receptor, and others [111]. Functional PI3K is recruited to the plasma membrane converting phosphatidylinositol $(4,5)$-bisphosphate $\left(\mathrm{PIP}_{2}\right)$ to phosphatidylinositol $(3,4,5)$-triphosphate $\left(\mathrm{PIP}_{3}\right)$. Subsequently, $\mathrm{PIP}_{3}$ localizes Akt to the plasma membrane and binds to the pleckstrin homology (PH) domain of Akt/Pkb which leads to activation of Akt [112]. Activated Akt plays an important role in the phosphorylation and inhibition of downstream signaling proteins such as Bcl-associated death promoter (Bad), Bax, Glycogen Synthase Kinase 3 (GSK3), and FOXO transcription factors thereby initiating cell cycle progress and inhibiting apoptotic signals. Moreover, Akt also indirectly activates 
mTOR which is involved in cell growth and metabolism via phosphorylation and inhibition of tuberous sclerosis complex 1/2 (TSC 1/2) $[113,114]$. As a result, activation of these targets contributes to elevation of cell proliferation, metabolism, growth, and survival. Accumulating evidences have shown that PI3K/Akt/mTOR pathway is deregulated in lung cancer and has been associated with high-grade tumors, advanced disease, and poor prognosis [114,115]. Alteration of PI3K/Akt/mTOR pathway was found in $50 \%-70 \%$ of NSCLC cases [114,116] and approximately $36 \%$ of SCLC cases [117].

Curcumin was shown to inhibit PI3K/Akt/mTOR pathways in NSCLC cells A549 [118] and H1299 [119]. The findings demonstrated that curcumin treatment suppresses the PI3K/Akt/mTOR pathway by decreasing the Akt and mTOR phosphorylation thus inducing apoptosis $[119,120]$. On a different note, a tumor suppressor phosphatase and tensin homolog (PTEN) protein has been found to inactivate PI3K/Akt/mTOR pathways through dephosphorylation of $\mathrm{PIP}_{3}$ to $\mathrm{PIP}_{2}$ [121]. Reduction or absence of PTEN has been observed in 30\% to 70\% of NSCLC [122,123] and $8 \%$ to $40 \%$ of SCLC [124-126]. Curcumin also has been shown to increase PTEN expression via modulation of miR-21 in NSCLC cells A549 which leads to activation of PI3K/Akt/mTOR pathway followed by induction of apoptosis [127].

\subsubsection{Reactive Oxygen Species (ROS)}

Reactive oxygen species (ROS) are highly reactive radicals, ions, or molecules that contain unpaired electrons and are formed by the partial reduction of molecular oxygen [128]. It is well documented that elevated levels of ROS has been found in multiple types of cancers including lung cancer cells. Accumulation of ROS leads to uncontrolled cell proliferation, angiogenesis, metastasis, and resistance to apoptosis in cancer cells [129].

Several studies have been demonstrated that curcumin exhibits apoptosis in multiple cancer cells including lung cancer through ROS or oxidative stress signaling pathway. Previous studies on SCLC NCI-H446 [130] and NSCLC A549 [131] cells treated with curcumin showed induction of apoptosis via reactive oxygen species-mediated mitochondrial pathway. The findings in these studies found that curcumin increased Bax expression but downregulated Bcl-2 and Bcl- $\mathrm{X}_{\mathrm{L}}$ expression, leading to a decrease in mitochondrial membrane potential. Subsequently, cytochrome $C$ release in combination with an apoptotic protease-activating factor (Apaf-1) contributes to the formation of a complex known as apoptosome, which activates caspase- 9 followed by caspase-3 $[130,131]$.

Another study conducted by Yao and co-workers demonstrated that HSP70 was involved upon elevation of ROS production by NSCLC A549 cells treated with curcumin followed by induction of apoptosis. HSP70 is expressed highly under stress conditions, such as heat shock as well as oxidative stress. It has been indicated that HSP70 was highly expressed in tumor cells and associated with histological types of lung cancer and prognosis. High levels of HSP70 activate the Bcl-2 protein family and inactivate caspase 9, thus causing inactivation of caspase 9, which affects the cytoplasm of the caspase cascade and inhibits apoptosis. Curcumin has been found to suppress the activity of HSP70 via intracellular redox state regulation, and as a result, the mitochondrial apoptotic pathway was activated. [132]. In addition, it has been demonstrated that curcumin induces apoptosis in NSCLC A549 cells via ROS and mitogen-activated protein kinase (MAPK) signaling pathways [131,132]. The MAPK pathways regulated by ROS are closely associated with cell proliferation and differentiation as well as necrosis. MAPK pathway includes 3 major kinases which are ERK, JNK, and P38. The ERK kinase plays a role in cell differentiation and proliferation [133], and meanwhile JNK and P38 are involved in the regulation of cell apoptosis $[134,135]$. In this study, phosphorylated JNK and p38 proteins were increased in response to curcumin, whereas ERK was reduced in a dose-dependent manner. The results showed that curcumin induces apoptosis in A549 cells through the activation of MAPK signaling pathway, and expression of p38, JNK, and ERK proteins [132,136].

\subsubsection{Fas-Fas Ligand interactions}

Fas (CD95 or APO-1) serves as a cell surface receptor which its role is pivotal for apoptotic signaling in different types of cells $[137,138]$. The Fas receptor binds with FasL, a natural ligand that 
belongs to a member of the tumor necrosis factor superfamily to initiate the death signal cascade, hence resulting in apoptosis via extrinsic and intrinsic pathways $[139,140]$. The Fas receptor has been found widely in numerous type of tissues, while FasL expression is commonly found in immune system cells such as activated T cells and natural killer cells, and the cells within immune privileged areas, such as the reproductive organs and eyes [141-143]. Nonetheless, decreased expression of Fas and/or increased expression of FasL has been detected in multiple types of human cancer, including lung cancer, and appears to be a feature of the malignant phenotype, suggesting that the Fas/FasL system may play an important role in cancer formation $[144,145]$. There is a strong evidence demonstrating that decreased expression of Fas may protect transformed cells from elimination by anti-tumor immune responses, but heightened expression of FasL may increase the ability of tumor cells to counterattack the immune system by killing Fas sensitive lymphocytes and therefore contribute to lung cancer development [146-150]. Curcumin has been reported to increase Fas/CD95 expression as well as caspase-8 activity in NCI-H460 cells suggesting that extrinsic apoptotic pathway was activated following the treatment. These findings were further confirmed by a significant increase in cell viability after pre-treatment of curcumin-treated NCI-H460 cells with caspase-8 inhibitor [103].

As summarized in Figure 2, curcumin induces apoptosis through the modulation of numerous molecular targets that are involved in intrinsic and extrinsic pathways of apoptosis. Thus, it can be suggested that targeting the molecular pathways of apoptosis is one of the effective approaches in lung cancer therapy.

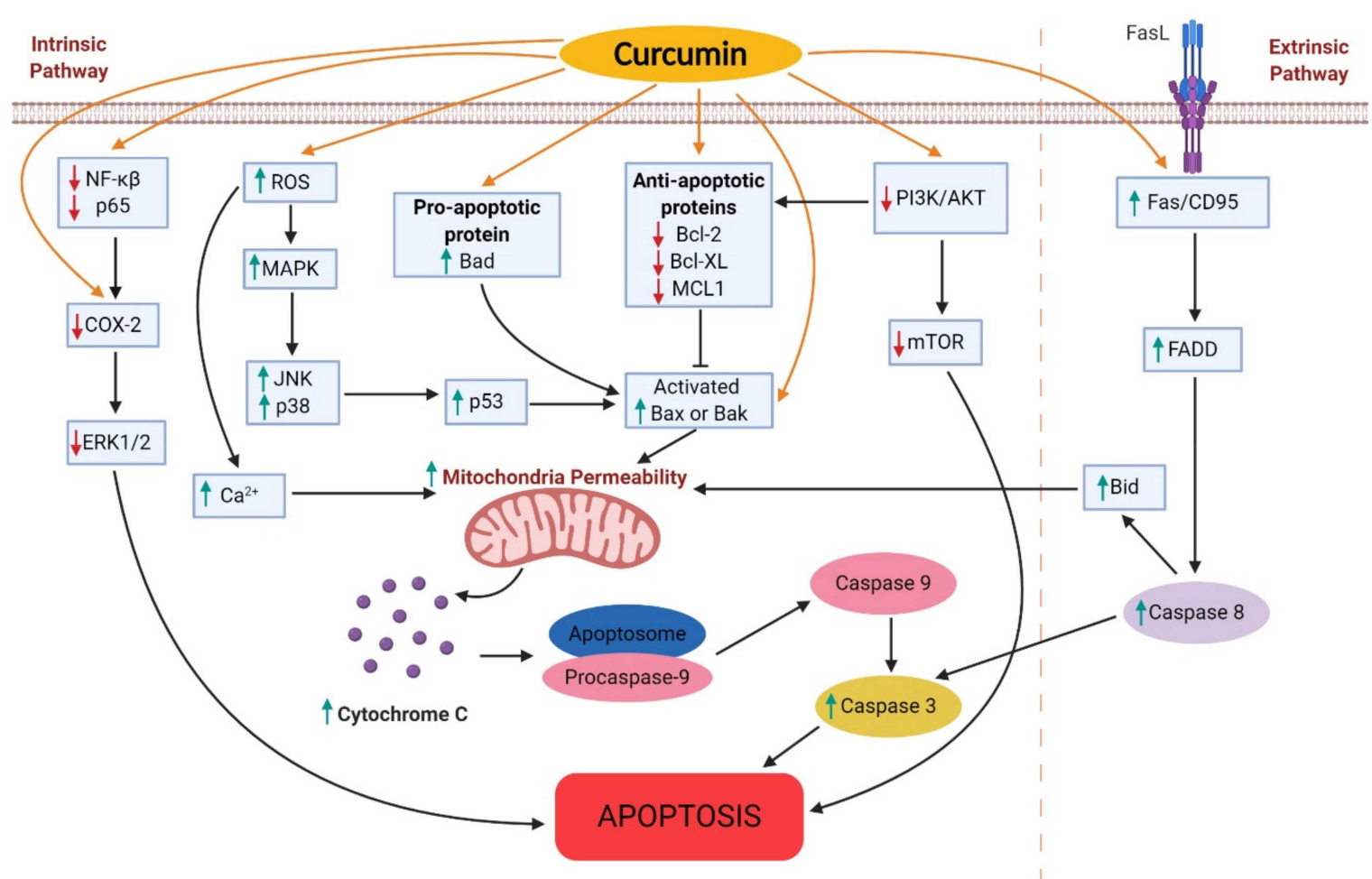

Figure 2. Molecular targets of curcumin in inducing cell apoptosis of lung cancer cells. The green arrow indicates upregulation, while the red arrow indicates downregulation of molecular targets. NF-кB: nuclear factor kappa-light-chain-enhancer of activated B cells; COX-2: cyclooxygenase-2; ERK1/2: extra-cellular signal regulated kinase: ROS: reactive oxygen species; MAPK: mitogen-activated protein kinase; JNK: Jun N-terminal kinase; PI3K: phosphatidylinositol 3-kinase; Akt: protein kinase; mTOR: mammalian target of rapamycin; Bad: Bcl-2-associated death promoter; Bcl-2: B-cell lymphoma-2; BCL-xL: B-cell lymphoma-extra large; MCL1: induced myeloid leukemia cell differentiation protein; FADD: Fas-associated protein with death domain. 


\subsection{Effects on Cell Invasion and Metastasis}

Tumor metastasis is a multistep event which includes alteration in various biochemical, genetic, and epigenetic factors in the primary tumor that contributes to the invasion-metastasis cascade [151].

It has been shown that curcumin inhibits metastasis in lung cancer cells by modulating several molecular targets including Cdc42, E-Cadherin, matrix metalloproteinases (MMPs), VEGF, and adiponectin.

\subsubsection{Cell Division Cycle 42 (Cdc42)}

Cell division cycle 42 (Cdc42) is a member of Rho family of GTPases, which serves as an important molecular switch converting an inactive GDP-bound form to an active GTP-bound form in response to diverse signals. The activation of $\mathrm{Cdc} 42$ is regulated by guanine nucleotide exchange factors (GEFs), GTPase activating proteins (GAPs) and guanine nucleotide dissociation inhibitors (GDIs) [152]. Activated Cdc42 involves in many cellular processes such as cell polarity, actin filopodia formation, directional migration, and cell proliferation [153-156]. Overexpression of Cdc42 has been found in several types of cancers including lung cancer and it has been associated with tumor carcinogenesis as well as progression [157-159]. Additionally, accumulating evidences showed that Cdc42 plays a crucial role as metastasis regulator in human cancer models $[160,161]$. There is evidence to suggest that Cdc42 is involved in both the formation of invadopodia structures as well as the production and/or activation of MMPs responsible for the ECM digestion necessary for tumor cell invasion [154]. It has been documented that curcumin suppressed migration and invasion of cancer cells by downregulating Cdc 42 expression in human cancer cells including lung cancer. A study conducted on human lung cancer cells A549 and 801D treated with curcumin demonstrated that curcumin downregulated Cdc-42 expression in a dose-dependent manner. The expression of Cdc42 targeting genes such as cofilin, E-cadherin, and PAK1 also has been observed to change significantly in treated cells, suggesting that curcumin could cause anti-metastatic effects by suppressing the transcriptional level of Cdc42. Additionally, this study revealed that curcumin was able to induce rearrangement of the actin cytoskeleton as well as be involved in formation of actin filopodia, hence further strengthening the anti-metastatic activity in both A549 and 801D cells [162].

\subsubsection{Epithelial Cadherin (E-Cadherin)}

E-cadherin also known as Cadherin 1 is an epithelial cell-cell adhesion molecule that functions in mediating cell-cell adhesion through calcium-dependent binding between two E-cadherin molecules at the surface of adjacent cells [163]. E-cadherin which is a transmembrane glycoprotein plays a key role in epithelial cell behaviour and cellular adhesion $[164,165]$. Numerous evidences have shown that the impairment and loss of function of E-cadherin were associated with cells characteristic with malignant transformation [166,167]. In addition, downregulation of E-cadherin is frequently found in tumors with extensive lymph node metastasis and infiltrative growth, suggesting that reduced level of E-cadherin contributes to cancer cell metastasis and invasion [168-172]. Previous study has shown that low expression of E-cadherin was detected in approximately $63 \%$ of lung carcinomas and $23 \%$ of lung adenocarcinomas [173].

It has been reported that curcumin is able to up-regulate the E-cadherin expression in multiple cancer cells including lung cancer, inhibiting cell invasion and metastasis. In a study with mice lung cancer, curcumin has been demonstrated to up-regulate the expression of E-cadherin through activation of heat shock protein 40 (HLJ1) also known as DNAJB4. HLJ1 activation is linked with progression of human cancer through modulation of cell proliferation, differentiation, apoptosis, invasion, and metastasis. The findings of this study also suggested that curcumin modulates HLJ1 by increasing JNK/JunD expression and subsequently reduced filopodia formation that would enhance the inhibitory activity of cell invasion and metastasis [174]. 


\subsubsection{Matrix Metalloproteinases (MMPs)}

Matrix metalloproteinases (MMPs), a family of zinc-dependent endopeptidases play a pivotal role in proteolysis of the extracellular matrix (ECM) as these enzymes have the capability to cleave and degrade several macromolecules of ECM. In normal physiological conditions, MMPs contributes to tissue morphogenesis, organ development, wound healing, reproduction, and apoptosis, as well as angiogenesis [175]. Deregulation of MMPs has been reported to cause several pathological conditions including tumor invasion and metastasis [176-178]. Overexpression of MMPs particularly MMP-2 (Gelatinase A) and MMP-9 (Gelatinase B) has been associated with tumor progression, metastasis, and poor prognosis $[179,180]$. Numerous evidences have shown that curcumin is able to inhibit metastasis and progression of cancer cells by decreasing the expression and activity of MMPs, particularly MMP-9 and MMP-2 [181-184]. It has been reported that curcumin inhibits MMP-2 and MMP-9 expression in human NSCLC A549 cells through downregulation of the MEKK and ERK signaling pathways [185]. These protein kinases were associated with MMPs biosynthesis and have been associated with regulation of cancer cell proliferation and invasion $[186,187]$. This study also demonstrated that VEGF expression was downregulated indicating anti-metastatic effect in A549 cells [185]. MMP-9 may act as an angiogenic switch due to its ability to increase the bioavailability of angiogenic factors including VEGF, which is the most potent mediator of tumor vasculature [188,189]. Hence, downregulation of MMP-9 correlated with decreased expression of VEGF, resulting in inhibition of angiogenesis and metastasis.

Another study by Chen and colleagues on human large cell lung carcinoma 801D cell line showed that the inhibitory effect of curcumin on the invasion and migration associated with decreased MMP-2 and MMP-9 expression via the inhibition of the Rac1/PAK1 signaling pathway [190]. It has been indicated that Rac1 is involved in the regulation of actin cytoskeleton rearrangement which further strengthens the anti-invasion effect of curcumin on 801D cell line [191]. In addition, curcumin has been found to reduce MMP-9 protein level in A549 cells by downregulating PKC $\alpha$, NOX-2, and ATF2 expression, and inhibiting ROS intracellular production in lung cancer A549 cells. As described previously, NOX-2 is activated by PKC $\alpha$ which in turn promote ROS generation and subsequently activate ATF2. Activated ATF2 then facilitates AP1-binding to the MMP-9 promoter resulting in MMP-9 expression. This study demonstrated that inhibition of PKC $\alpha / N O X-2 / R O S / A T F 2$ signaling pathway decreases expression of MMP-9, suggesting one of the mechanisms of anti-invasive effect by curcumin in lung cancer cells [192].

\subsubsection{Adiponectin}

Adiponectin is a peptide hormone produced solely by adipose tissue, which has the function to serve as an anti-atherogenic hormone by inhibiting proliferation of vascular smooth muscle cells and endothelia cells [193]. Adiponectin expression is highly associated with the risk of cancer in obesity-associated cancers such as hematologic malignancies, renal cancer, colon cancer, post-menopausal breast cancer, and endometrial cancer [194]. Whereas, low expressions of adiponectin have been detected in gastric [195] and prostate [196,197] cancers. In lung cancer, it has been reported that adiponectin is not a major predictor of risk as the expression was not significantly different compared to the control group. However, adiponectin receptors (1 and 2$)$ that play a crucial role in adiponectin activation were expressed only in cancerous lung tissues, suggesting that adiponectin functional signaling mediates lung cancer development [198]. It has also been reported that lung cancer patients with decreased adiponectin concentration are associated with longer survival time. In addition, a significant higher adiponectin expression has been observed in NSCLC patients with metastasis compared to those without metastasis [199].

Tsai et al. showed that curcumin inhibits the migratory and invasive behaviour of NSCLC A549 cells. It has been shown that curcumin blocks the adiponectin receptor 1 which inhibits the adiponectin expression. Adiponectin demonstrated anti-metastatic activity by suppressing tumor angiogenesis 
and downregulating MMPs. This study suggested that curcumin inhibits metastasis of NSCLC cells through adiponectin/ NF-kB/MMP pathways [199].

Taken together, as shown in Figure 3, the findings of the studies above indicated that curcumin may act as potential anti-angiogenic and anti-metastatic agent for lung cancer cells and further research is warranted to elucidate detail mechanisms governed by curcumin in lung tumor dispersal.

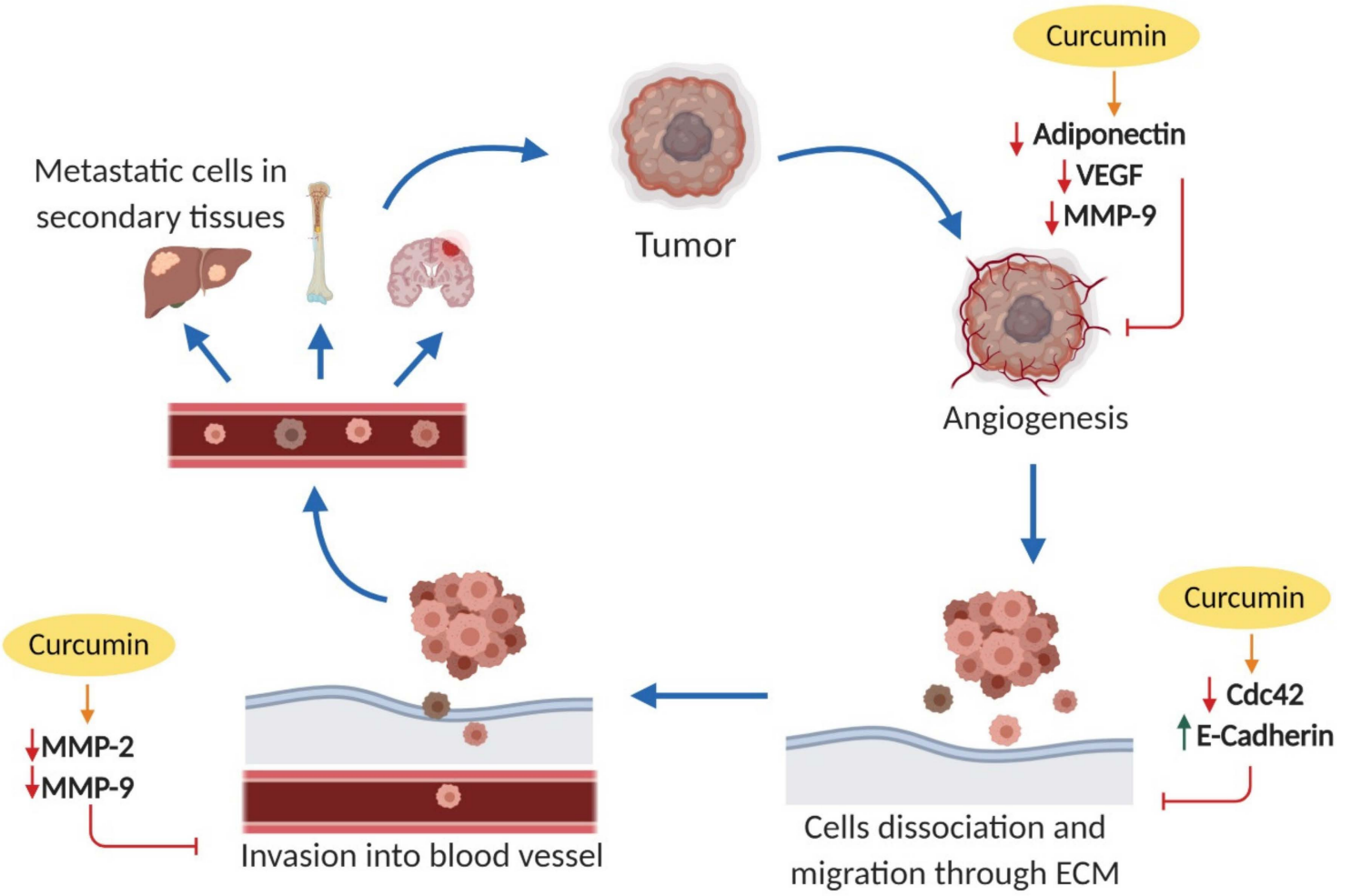

Figure 3. Molecular mechanism of anti-metastasis effect by curcumin against lung cancer cells. The green arrow indicates upregulation, while the red arrow indicates downregulation of molecular targets. VEGF: vascular endothelial growth factor; MMP-2: matrix metalloproteinase; MMP-9: matrix metalloproteinase-9; Cdc-42: cell division cycle 42.

\subsection{Effects on Epigenetic Changes}

Epigenetic refers to heritable changes in gene expression that occur without a change in the DNA sequence, which leads to the activation and/or silencing of multiple genes [200,201]. There are several mechanisms involve in epigenetic modification which are interconnected to selectively modulate gene expression, including DNA methylation and histone modifications [202]. Curcumin has recently been shown to induce epigenetic changes through the regulation of histone deacetylases (HDACs), histone acetyltransferases (HATs), and DNA methyltransferase 1 (DNMT1) activity that result in the activation or inactivation of the gene expression involved in cancer death and progression [203,204].

DNA methylation is a covalent DNA modification that occurs mostly at $5^{\prime}$ position of the cytosine residues within cytosine-phosphate-guanine $(\mathrm{CpG})$ dinucleotides. Moreover, it may also occur at cytosine-phosphate-adenine (CpA) and cytosine-phosphate-thymine $(\mathrm{CpT})$ dinucleotides. This reaction is catalysed by DNA methyltransferase (DNMT) and S-adenosyl-methionine (SAM) as the methyl donors [205]. There are two patterns of DNA methylation that have been observed in cancer cells which include global hypomethylation and localized hypermethylation [202]. Global hypomethylation at repetitive sequences could result in genomic instability that can favor mitotic recombination followed by deletions and translocations as well as chromosomal rearrangement. This leads to activation of proto-oncogenes and pro-metastatic genes which contribute to cancer development [206,207]. Localized hypermethylation at the CpG island promoter leads to transcriptional 
silencing of tumor suppressor and DNA repair genes, and the inability to regulate cell cycle control, apoptosis, cell adhesion, and metastasis [208]. It has been documented that curcumin exerts anti-cancer effects against leukemia [209], cervical [210,211], melanoma [212], breast [213], and prostate [214] cancer cells through global hypomethylation which reactivates the silenced tumor suppressor and DNA repair genes thus inhibits the cancer progression $[215,216]$. To date, there is no study reported on curcumin as a hypomethylating agent against lung cancer cells. However, other curcuminoids, namely demethoxycurcumin and bisdemethoxycurcumin have been shown to induce demethylation effect in NSCLC cell lines A549, H460 and SPC-A-1. In this study, the demethylating effect of curcumin leads to restoration of tumor suppressor gene Wnt inhibitory factor-1 (WIF1) expression whose promoter is hypermethylated and silenced in lung cancer cells and tissues (Figure 4). As a result of WIF-1 restoration, the Wnt pathway is downregulated causing inhibition of cancer cell growth [217].

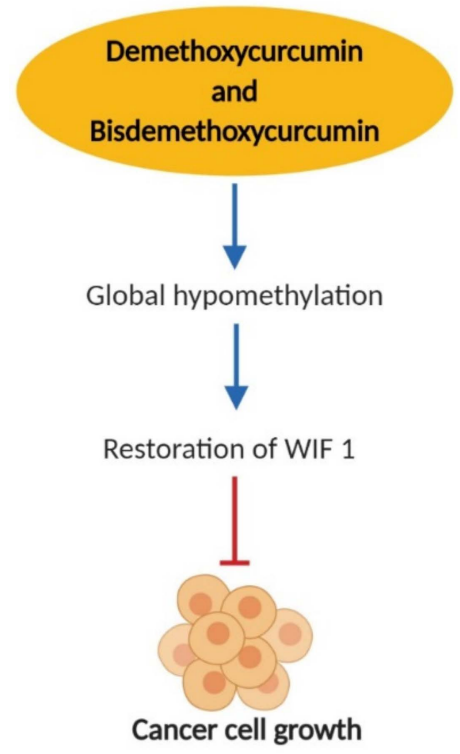

Figure 4. Epigenetic effect of demethoxycurcumin and bisdemethoxycurcumin on lung cancer cells. WIF 1: Wnt Inhibitory Factor-1.

Histone modification is one of the epigenetic alterations that affects chromatin structure and function, and is subsequently involved in chromatin-based processes such as gene transcription, DNA repair, and DNA replication [218,219]. Histones (H3, H4, H2A, H2B and H1) are highly conserved core proteins of chromatin structure that subject to posttranslational modifications including lysine acetylation, ADP-ribosylation, ubiquitination, and sumoylation that occur on $\mathrm{N}$ - or C-terminal tail domains [220,221]. Alteration in histone acetylation has been extensively studied as it contributes to tumorigenesis [222-224]. Studies performed on brain cancer [225], burkitt lymphoma [226], and prostate cancer cells [227] pointed out that curcumin could be considered as a strong modulator of HDAC or HAT activity [204]. However, to date, the studies and investigations on the anti-cancer effect of curcumin in lung cancer through histone modifications remain scarce. Therefore, more investigations are warranted to elucidate the role of curcumin as a HDAC and HAT modulator in lung cancer cells.

\subsection{The Role of MicroRNA (MiRNA)}

MiRNAs are small noncoding regulatory RNAs, ranging from 19 to 25 nucleotides and are responsible to regulate gene expression at the post-transcriptional level. Furthermore, miRNAs play important roles in cell growth, proliferation, differentiation, and mobility as well as apoptosis [228,229]. Alteration in the expression of miRNAs and processing of miRNA precursors, or presence of mutations in the sequence of miRNA may have detrimental effects on cellular function and have been associated with cancer $[230,231]$. It has been demonstrated that miRNAs have an important role in the pathogenesis 
of lung cancer and development of drug-resistance [232]. A number of studies have reported an aberrant expression of miRNAs in lung tumors compared with the corresponding normal lung tissues, suggesting the involvement of miRNAs in lung cancer pathogenesis [233]. It has been described in numerous NSCLC studies that miRNAs with tumor suppressor activity are down-regulated meanwhile those with oncogenic function are upregulated [234-237]. For example, miR-34, a miRNA with tumor suppressor activity is downregulated in NSCLC cell lines. In response to DNA damage, miR-34 is activated by $\mathrm{p} 53$ which targets $B C L-2, M Y C, M E T$, and PDGFR genes which were associated with cell cycle regulation and apoptosis [238].

Recent evidences have shown that the pharmacological effects of curcumin in lung cancer are also mediated by modulation of several miRNAs [239]. Curcumin has been found to inhibit cancer cell growth through modulation of miRNAs such as miR-15a, miR-16, miR-21, miR-22, miR-26, miR-101, miR-146, miR-200, miR-203, and let-7, and their multiple targets genes in various types of cancer cells including lung cancer [239-242]. It has been documented that curcumin upregulated miR-16 in human lung adenocarcinoma A549 cells in which it modulates miRNA profile by upregulating eight miRNAs and downregulating six other miRNAs in which miRNA-186* is the most affected. Inhibition of miRNA-186* expression subsequently leads to upregulation of caspase-10 whereby inducing apoptosis, thus inhibiting A549 cell growth [243]. Similarly, it has been observed that curcumin downregulated miRNA-186* in cisplatin A549/DDP multidrug resistant human lung adenocarcinoma cells [244]. Taken together, these findings suggest that curcumin inhibits cell proliferation and induces apoptosis in lung cancer cells as well as drug-resistant tumor cell through downregulation of miRNA-186*.

In addition, it has been reported that curcumin also caused a significant reduction of miR-21 expression by $60 \%$ in A549 lung cancer cells. It was indicated that the miR-21 elevates PTEN expression which inhibits cell proliferation and induces apoptosis [127]. The effect of curcumin on miRNA modulation was further demonstrated by Ye and co-workers in a study with p53 wild type H460, A427, and A549 cells. The authors showed that curcumin promoted miR-192-5p/215 upregulation, followed by activation of X-linked inhibitor of apoptosis (XIAP) signaling pathway and therefore induced apoptosis in p53 wild type lung cancer cells such as H460, A427, and A549 cells [245]. Similarly, Jin et al. also revealed that curcumin promoted upregulation of miRNA-192-5p in A549 cells, which suppresses the P13K/Akt signaling pathway. Consequently, curcumin inhibited cell proliferation and induced apoptosis in A549 NSCLC cells, as the P13K/Akt pathway plays an important role in growth factor-mediated cell survival [246].

Furthermore, curcumin has been shown to up-regulate miR-874 in A549 and H1299 cell lines which in turn targets and suppresses MMP-2 expression. It has been indicated that MMP-2 involved in the degradation of extracellular matrix facilitating the process of metastasis. Hence, downregulation of MMP-2 through upregulation of miR-874 by curcumin inhibits invasion and metastasis in A549 and H1299 cells [247]. In addition, curcumin upregulated miRNA-let7c and miR-101 in A549 cells which downregulated $E Z H 2$ via activation of NOTCH signaling pathway. $E Z H 2$ is an oncogene that regulates the cell cycle and progression thus downregulation was shown to inhibit proliferation of A549 cancer cells [248].

In a recent study, Liu et al. demonstrated that curcumin upregulates the expression of miR-98 in A549 cells followed by downregulation of LIN28A, which inhibits MMP-2 and MMP-9 activity. These findings suggested that curcumin suppressed lung cancer cell migration and invasion through activation of miRNA-98/LIN-28A/MMP-2/-9 pathways [249].

As previously described, miRNAs play an important role in the pathogenesis of lung cancer and could serve as potential therapeutic targets for lung cancer treatment. In addition, as summarized in Figure 5, all of the above findings provide an insight into the role of curcumin as potential anti-cancer agent through the modulation of miRNAs. Therefore, further investigations are crucial in this promising field to explore the link between regulation of oncogenic and tumor suppressive miRNAs and curcumin as an anti-cancer agent. 


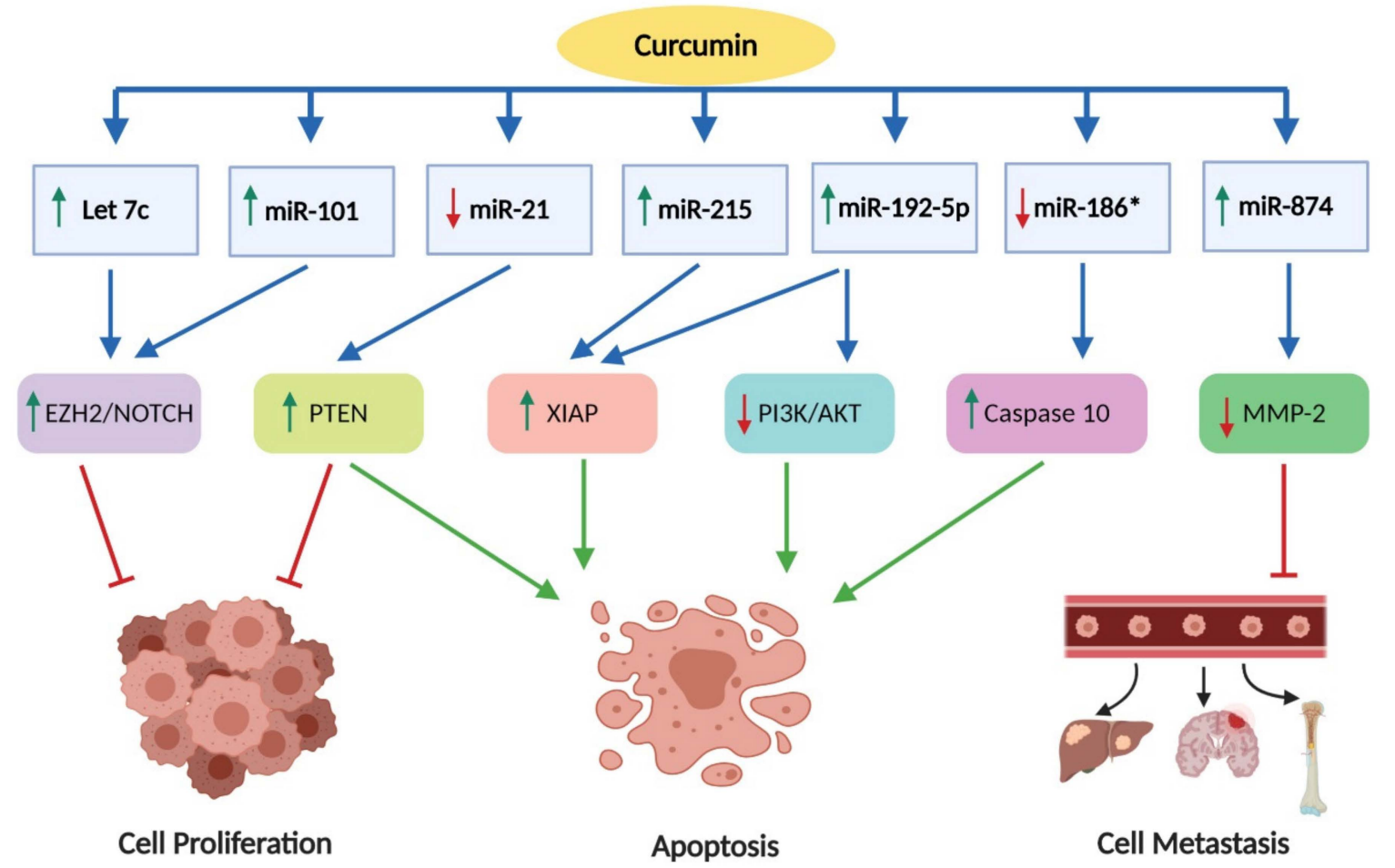

Figure 5. Modulation of microRNA by curcumin against lung cancer cells. The green arrow indicates upregulation, while the red arrow indicates downregulation of molecular targets and microRNAs. EZH2: enhancer of zeste homolog 2; Notch-1: neurogenic locus notch homolog protein-1; PTEN: phosphatase and tensin homolog; XIAP: X-linked inhibitor of apoptosis protein; PI3K: phosphatidylinositol 3-kinase; Akt: protein kinase; MMP-2: matrix metalloproteinase-2.

\section{Curcumin Bioavailability Limitation and Strategies to Overcome}

Pharmacokinetic profile studies of curcumin have revealed that curcumin has poor absorption as well as rapid metabolism that severely renders its bioavailability [250,251]. This is due to the metabolism of curcumin that involves glucuronidation, sulfation, and reduction which results in the formation of metabolites that have poor cell permeability and very short half-life [252]. Pan et al. reported that $99 \%$ of curcumin in plasma present as glucuronide conjugates in curcumin-treated animals. This study also showed that reduction products of curcumin such as di- and tetra-hydrocurcumin and glucuronosides of curcumin are major metabolites of curcumin in vivo [253]. These curcumin conjugates and metabolites have been revealed to play an important role in several therapeutic effects such as anti-oxidation [254], anti-inflammation [255], and anti-cancer [256]. However, multiple studies have highlighted that the anti-cancer activity by curcumin conjugates and metabolites is less potent compared to the parent curcumin [257-259]. Therefore, numerous strategies including improvised formulation and structural modification have been established to compensate the bioavailability limitation of curcumin [259].

Previous study by Shoba et al. have documented that the use of an adjuvant such as piperine increases curcumin bioavailability in both rats and humans by $154 \%$ and $2000 \%$ respectively via inhibition of glucuronidation. Piperine $(20 \mathrm{mg} / \mathrm{kg})$ also has ability to reduce the time duration for curcumin to achieve increased serum concentrations with no evidence of harmful results [260]. In addition, a nanoparticle of curcumin formulation has been extensively investigated to enhance the solubility and bioavailability of curcumin [261,262]. It has been found that nanocurcumin has similar effects with curcumin in reducing inflammatory responses and cell death induction against human pancreatic cancer cell lines [263]. However, the in vivo effect of this nanocurcumin is yet to be assessed. Furthermore, Ling and co-investigators revealed that a cationic liposome-PEG-PEI complex (LPPC) has been used as a carrier for the encapsulation of hydrophobic curcumin to produce 
curcumin/LPPC complex against 10 different cancer cells including A549 cells and LL2 mice lung carcinoma cells. This study found that the cytotoxic activity of the curcumin/LPPC was more active in 10 different cancer cells in vitro by 3.9-20 fold compared to curcumin alone. It has been suggested that the increased cytotoxic activity of curcumin/LPPC is likely attributable to its rapid accumulation in the cell [264]. It also has been reported that polymeric micellar curcumin increases the biological half-life by 60-fold in rats compared to curcumin solubilized in a mixture of PEG and dextrose [265]. Similarly, Liu et al. reported that curcumin phospholipid complex increases the elimination half-life by 1.5 fold compared to free curcumin [266]. Furthermore, curcumin analogues, and derivatives of curcumin have been widely studied in recent years. A curcumin analogue EF-24 has shown to increase absorption, produce a peak plasma level of $1000 \mathrm{nM}$, and increase the elimination half-life in mice [267]. Based on the findings mentioned above, it can be concluded that all of the approaches to counter the bioavailability issue of curcumin such as the use of adjuvants, nanoparticles of curcumin, liposomal curcumin, and analogs of curcumin may provide a new tool for cancer therapy.

\section{Curcumin and Its Potential Side Effects}

Despite several studies showed the positive biological effects of curcumin, there are studies have also highlighted the adverse effects and toxicity of curcumin intake $[20,268,269]$. As reported by The National Toxicology Program, there are long term as well as short term adverse effects of dietary turmeric oleoresin (79.85\% similar to curcumin) in F3441N rats and B6C3F1 mice. This study was conducted by administering turmeric oleoresin in these animals at different concentrations $(1000,5000$, $10,000,25,000$ or 50,000 ppm that delivers daily doses of 50,250, 480, 1300, or $2600 \mathrm{mg} / \mathrm{kg}$ body weight) for 13 weeks and two years. In a short term (13-week) study, the toxicological signs showed an increase in liver weight, stained fur, discoloured faces, and hyperplasia of cecum and colon in both female and male rats. In addition, no sign of carcinogenic lesions and no death were observed in both female and male rats. As for a long term rats evaluation (two years), no mortality was reported while the adverse effects include incidence of ulcers, chronic inflammation, and hyperplasia of the cecum and forestomach. In addition, this study also reported the carcinogenic effects of curcumin oleoresin such as the increase in clitoral gland adenomas in female rats, hepatocellular adenomas in female mice, and intestinal carcinoma along with hepatocellular adenomas in male mice [270].

Previous study also revealed that curcumin at $25 \mathrm{~g} / \mathrm{kg}$ feed significantly inhibited cyclophosphamide activity to decrease the tumor size in human breast cancer xenograft in nude mice [271]. In addition, curcumin also is proven to exhibit pro-oxidant activity, which leads to ROS generation by irreversibly modifying thioredoxin reductase and which initiates carcinogenesis [272-274]. It also has been reported that curcumin has the ability to cause DNA damage to mitochondrial and nuclear genomes in an in vitro study on HepG2 human hepatocellular carcinoma cells [275]. However, to date, no long term human trials with curcumin have been confirmed for its toxicity and adverse effects. However, minor adverse effects of curcumin intake in humans such as diarrhea has been reported [276].

Furthermore, early phase trials in humans have shown that curcumin can be regarded as a safe dietary supplement. As reported by Kanai and colleagues in a phase I/II human study, curcumin is safe to be consumed at doses as high as $8 \mathrm{~g} /$ day [277]. The Food and Drug Administration also has classified curcumin as "generally regarded as safe" (GRAS) with the panel's conclusion that curcumin GRAS status applies for a maximal administration of $20 \mathrm{mg} /$ serving or $180 \mathrm{mg} /$ day of curcumin [268].

\section{Clinical Trials}

In response to multiple in vitro and in vivo studies of curcumin in cancer cells, extensive clinical trials have been conducted on curcumin against different human cancers including pancreatic, colon, breast, cervical, and uterine $[278,279]$. The clinical use of curcumin in trials both as a monotherapy as well as in combination with other drugs has been shown to have anti-cancer effects, while retaining its safety [24]. Despite numerous clinical trials of curcumin in various human cancers, clinical trial of 
curcumin in lung cancer patients remains scarce. Therefore, more clinical trials of curcumin in lung cancer patients are needed to test its efficacy and safety as a potential therapeutic agent for lung cancer.

\section{Conclusions}

Taken together, curcumin holds a highly promising potential alternative therapy for lung cancer with less adverse effects. Curcumin exerts its anti-cancer effects in lung cancer by modulating various molecular targets, signaling pathways, epigenetics alteration, and microRNAs expression. However, the clinical application of curcumin currently is limited due to poor bioavailability, and several strategies have been evaluated to overcome this issue, thus enhancing its efficacy in lung cancer treatment. In future, a greater focus on the mechanism of curcumin by multi-omics technologies as well as clinical trials in lung cancer patients could provide more comprehensive information in understanding the therapeutic effects of curcumin against lung cancer.

Author Contributions: W.N.B.W.M.T. designed the outline of the manuscript and wrote the manuscript; R.N. designed the outline of the manuscript, and edited and revised the manuscript; I.O., N.H.L., and F.A. edited and revised the manuscript.

Funding: This study is financially supported by the Monash Global Asia in the 21st Century (GA21) research grant (GA-HW-19-L03).

Acknowledgments: The authors are thankful to Monash University Malaysia, for providing financial support to conduct this study.

Conflicts of Interest: The authors declare no conflict of interest.

\section{References}

1. Torre, L.A.; Bray, F.; Siegel, R.L.; Ferlay, J.; Lortet-Tieulent, J.; Jemal, A. Global cancer statistics, 2012. CA A Cancer J. Clin. 2015, 65, 87-108. [CrossRef] [PubMed]

2. Torre, L.A.; Siegel, R.L.; Ward, E.M.; Jemal, A. Global cancer incidence and mortality rates and trends-An update. Cancer Epidemiol. Prev. Biomark. 2016, 25, 16-27. [CrossRef] [PubMed]

3. Kwon, S.-B.; Kim, M.-J.; Ham, S.Y.; Park, G.W.; Choi, K.-D.; Jung, S.H.; Yoon, D.-Y. H9 induces apoptosis via the intrinsic pathway in non-small-cell lung cancer A549 cells. J. Microbiol. Biotechnol. 2015, 25, 343-352. [CrossRef] [PubMed]

4. Kogita, A.; Togashi, Y.; Hayashi, H.; SOGAbE, S.; Terashima, M.; De Velasco, M.A.; Sakai, K.; Fujita, Y.; TOMIdA, S.; Takeyama, Y. Hypoxia induces resistance to ALK inhibitors in the H3122 non-small cell lung cancer cell line with an ALK rearrangement via epithelial-mesenchymal transition. Int. J. Oncol. 2014, 45, 1430-1436. [CrossRef]

5. Miller, K.D.; Siegel, R.L.; Lin, C.C.; Mariotto, A.B.; Kramer, J.L.; Rowland, J.H.; Stein, K.D.; Alteri, R.; Jemal, A. Cancer treatment and survivorship statistics, 2016. CA A Cancer J. Clin. 2016, 66, 271-289. [CrossRef]

6. Hirsch, F.R.; Scagliotti, G.V.; Mulshine, J.L.; Kwon, R.; Curran, W.J., Jr.; Wu, Y.-L.; Paz-Ares, L. Lung cancer: Current therapies and new targeted treatments. Lancet 2017, 389, 299-311. [CrossRef]

7. Postow, M.A.; Callahan, M.K.; Wolchok, J.D. Immune checkpoint blockade in cancer therapy. J. Clin. Oncol. 2015, 33, 1974. [CrossRef]

8. Arriagada, R.; Dunant, A.; Pignon, J.-P.; Bergman, B.; Chabowski, M.; Grunenwald, D.; Kozlowski, M.; Le Péchoux, C.; Pirker, R.; Pinel, M. Long-term results of the international adjuvant lung cancer trial evaluating adjuvant Cisplatin-based chemotherapy in resected lung cancer. J. Clin. Oncol. 2010, 28, 35-42. [CrossRef]

9. Kato, H.; Tsuboi, M.; Kato, Y.; Ikeda, N.; Okunaka, T.; Hamada, C. Postoperative adjuvant therapy for completely resected early-stage non-small cell lung cancer. Int. J. Clin. Oncol. 2005, 10, 157-164. [CrossRef]

10. Bray, F.; Ferlay, J.; Soerjomataram, I.; Siegel, R.L.; Torre, L.A.; Jemal, A. Global cancer statistics 2018: GLOBOCAN estimates of incidence and mortality worldwide for 36 cancers in 185 countries. CA A Cancer J. Clin. 2018, 68, 394-424. [CrossRef]

11. Reck, M.; Heigener, D.F.; Mok, T.; Soria, J.-C.; Rabe, K.F. Management of non-small-cell lung cancer: Recent developments. Lancet 2013, 382, 709-719. [CrossRef] 
12. Imran, M.; Ullah, A.; Saeed, F.; Nadeem, M.; Arshad, M.U.; Suleria, H.A.R. Cucurmin, anticancer, \& antitumor perspectives: A comprehensive review. Crit. Rev. Food Sci. Nutr. 2018, 58, 1271-1293. [PubMed]

13. Lestari, M.L.; Indrayanto, G. Curcumin. In Profiles of Drug Substances, Excipients and Related Methodology; Elsevier: Amsterdam, The Netherlands, 2014; Volume 39, pp. 113-204.

14. Panahi, Y.; Hosseini, M.S.; Khalili, N.; Naimi, E.; Simental-Mendía, L.E.; Majeed, M.; Sahebkar, A. Effects of curcumin on serum cytokine concentrations in subjects with metabolic syndrome: A post-hoc analysis of a randomized controlled trial. Biomed. Pharmacother. 2016, 82, 578-582. [CrossRef]

15. Sahebkar, A.; Serban, M.-C.; Ursoniu, S.; Banach, M. Effect of curcuminoids on oxidative stress: A systematic review and meta-analysis of randomized controlled trials. J. Funct. Foods 2015, 18, 898-909. [CrossRef]

16. Zorofchian Moghadamtousi, S.; Abdul Kadir, H.; Hassandarvish, P.; Tajik, H.; Abubakar, S.; Zandi, K. A review on antibacterial, antiviral, and antifungal activity of curcumin. Biomed Res. Int. 2014, 2014. [CrossRef]

17. Um, M.Y.; Hwang, K.H.; Choi, W.H.; Ahn, J.; Jung, C.H.; Ha, T.Y. Curcumin attenuates adhesion molecules and matrix metalloproteinase expression in hypercholesterolemic rabbits. Nutr. Res. 2014, 34, 886-893. [CrossRef]

18. Miriyala, S.; Panchatcharam, M.; Rengarajulu, P. Cardioprotective effects of curcumin. In The Molecular Targets and Therapeutic Uses of Curcumin in Health and Disease; Springer: New York, NY, USA, 2007; pp. 359-377.

19. Vallianou, N.G.; Evangelopoulos, A.; Schizas, N.; Kazazis, C. Potential anticancer properties and mechanisms of action of curcumin. Anticancer Res. 2015, 35, 645-651.

20. Kumar, G.; Mittal, S.; Sak, K.; Tuli, H.S. Molecular mechanisms underlying chemopreventive potential of curcumin: Current challenges and future perspectives. Life Sci. 2016, 148, 313-328. [CrossRef]

21. Gupta, S.C.; Patchva, S.; Aggarwal, B.B. Therapeutic roles of curcumin: Lessons learned from clinical trials. AAPS J. 2013, 15, 195-218. [CrossRef]

22. Kastan, M.B.; Bartek, J. Cell-cycle checkpoints and cancer. Nature 2004, 432, 316. [CrossRef]

23. Evan, G.I.; Vousden, K.H. Proliferation, cell cycle and apoptosis in cancer. Nature 2001, 411, 342. [CrossRef] [PubMed]

24. Levy, D.E.; Lee, C.-K. What does Stat3 do? J. Clin. Investig. 2002, 109, 1143-1148. [CrossRef] [PubMed]

25. Zhong, Z.; Wen, Z.; Darnell, J.E. Stat3: A STAT family member activated by tyrosine phosphorylation in response to epidermal growth factor and interleukin-6. Science 1994, 264, 95-98. [CrossRef] [PubMed]

26. Zimmer, S.; Kahl, P.; Buhl, T.M.; Steiner, S.; Wardelmann, E.; Merkelbach-Bruse, S.; Buettner, R.; Heukamp, L.C. Epidermal growth factor receptor mutations in non-small cell lung cancer influence downstream Akt, MAPK and Stat3 signaling. J. Cancer Res. Clin. Oncol. 2009, 135, 723-730. [CrossRef]

27. Levy, D.E.; Darnell, J., Jr. Signalling: Stats: Transcriptional control and biological impact. Nat. Rev. Mol. Cell Biol. 2002, 3, 651. [CrossRef]

28. Yu, H.; Pardoll, D.; Jove, R. STATs in cancer inflammation and immunity: A leading role for STAT3. Nat. Rev. Cancer 2009, 9, 798. [CrossRef]

29. Bromberg, J.F.; Wrzeszczynska, M.H.; Devgan, G.; Zhao, Y.; Pestell, R.G.; Albanese, C.; Darnell, J.E., Jr. Stat3 as an oncogene. Cell 1999, 98, 295-303. [CrossRef]

30. Zhao, M.; Jiang, B.; Gao, F.-H. Small molecule inhibitors of STAT3 for cancer therapy. Curr. Med. Chem. 2011, 18, 4012-4018. [CrossRef]

31. Gao, S.P.; Mark, K.G.; Leslie, K.; Pao, W.; Motoi, N.; Gerald, W.L.; Travis, W.D.; Bornmann, W.; Veach, D.; Clarkson, B. Mutations in the EGFR kinase domain mediate STAT3 activation via IL-6 production in human lung adenocarcinomas. J. Clin. Investig. 2007, 117, 3846-3856. [CrossRef]

32. Haura, E.B.; Zheng, Z.; Song, L.; Cantor, A.; Bepler, G. Activated epidermal growth factor receptor-Stat-3 signaling promotes tumor survival in vivo in non-small cell lung cancer. Clin. Cancer Res. 2005, 11, 8288-8294. [CrossRef]

33. Johnson, F.M.; Saigal, B.; Talpaz, M.; Donato, N.J. Dasatinib (BMS-354825) tyrosine kinase inhibitor suppresses invasion and induces cell cycle arrest and apoptosis of head and neck squamous cell carcinoma and non-small cell lung cancer cells. Clin. Cancer Res. 2005, 11, 6924-6932. [CrossRef]

34. Pfeiffer, M.; Hartmann, T.; Leick, M.; Catusse, J.; Schmitt-Graeff, A.; Burger, M. Alternative implication of CXCR4 in JAK2/STAT3 activation in small cell lung cancer. Br. J. Cancer 2009, 100, 1949. [CrossRef] [PubMed]

35. Dutta, P.; Sabri, N.; Li, J.; Li, W.X. Role of STAT3 in lung cancer. Jak-Stat 2014, 3, e999503. [CrossRef] [PubMed] 
36. Harada, D.; Takigawa, N.; Kiura, K. The role of STAT3 in non-small cell lung cancer. Cancers 2014, 6, 708-722. [CrossRef] [PubMed]

37. Zhao, M.; Gao, F.-H.; Wang, J.-Y.; Liu, F.; Yuan, H.-H.; Zhang, W.-Y.; Jiang, B. JAK2/STAT3 signaling pathway activation mediates tumor angiogenesis by upregulation of VEGF and bFGF in non-small-cell lung cancer. Lung Cancer 2011, 73, 366-374. [CrossRef]

38. Yang, C.-L.; Liu, Y.-Y.; Ma, Y.-G.; Xue, Y.-X.; Liu, D.-G.; Ren, Y.; Liu, X.-B.; Li, Y.; Li, Z. Curcumin blocks small cell lung cancer cells migration, invasion, angiogenesis, cell cycle and neoplasia through Janus kinase-STAT3 signalling pathway. PLOS ONE 2012, 7, e37960. [CrossRef]

39. Wu, L.; Guo, L.; Liang, Y.; Liu, X.; Jiang, L.; Wang, L. Curcumin suppresses stem-like traits of lung cancer cells via inhibiting the JAK2/STAT3 signaling pathway. Oncol. Rep. 2015, 34, 3311-3317. [CrossRef]

40. Alexandrow, M.G.; Song, L.J.; Altiok, S.; Gray, J.; Haura, E.B.; Kumar, N.B. Curcumin: A novel stat 3 pathway inhibitor for chemoprevention of lung cancer. Eur. J. Cancer Prev. 2012, 21, 407. [CrossRef]

41. Tang, L.; Liu, J.; Zhu, L.; Chen, Q.; Meng, Z.; Sun, L.; Hu, J.; Ni, Z.; Wang, X. Curcumin inhibits growth of human NCI-H292 lung squamous cell carcinoma cells by increasing FOXA2 expression. Front. Pharmacol. 2018, 9, 60. [CrossRef]

42. Starok, M.; Preira, P.; Vayssade, M.; Haupt, K.; Salomé, L.; Rossi, C. EGFR Inhibition by Curcumin in Cancer Cells: A Dual Mode of Action. Biomacromolecules 2015, 16, 1634-1642. [CrossRef]

43. Yarden, Y.; Sliwkowski, M. Untangling the ErbB signalling network. Nat. Reviews. Mol. Cell Biol. 2001, 2, 127-137. [CrossRef] [PubMed]

44. Ye, M.-X.; Li, Y.; Yin, H.; Zhang, J. Curcumin: Updated molecular mechanisms and intervention targets in human lung cancer. Int. J. Mol. Sci. 2012, 13, 3959-3978. [CrossRef] [PubMed]

45. Engelman, J.; Janne, P.A. Mechanisms of acquired resistance to epidermal growth factor receptor tyrosine kinase inhibitors in non-small cell lung cancer. Clin. Cancer Res. 2008, 14, 2895-2899. [CrossRef] [PubMed]

46. Engelman, J.A.; Zejnullahu, K.; Mitsudomi, T.; Song, Y.; Hyland, C.; Park, J.O.; Lindeman, N.; Gale, C.-M.; Zhao, X.; Christensen, J.; et al. MET amplification leads to gefitinib resistance in lung cancer by activating ERBB3 signaling. Science 2007, 316, 1039. [CrossRef] [PubMed]

47. Yarden, Y. The EGF receptor family: Spearheading a merger of signaling and therapeutics. Cytom. Part $B$ Clin. Cytom. 2008, 74B, 388.

48. Mendelsohn, J.; Baselga, J. The EGF receptor family as targets for cancer therapy. Oncogene 2000, 19, 6550-6565. [CrossRef]

49. Klinger, B.; Sieber, A.; Fritsche-Guenther, R.; Witzel, F.; Berry, L.; Schumacher, D.; Yan, Y.; Durek, P.; Merchant, M.; Schäfer, R.; et al. Network quantification of EGFR signaling unveils potential for targeted combination therapy. Mol. Syst. Biol. 2013, 9, 673. [CrossRef]

50. Shafiee, M.; Mohamadzade, E.; ShahidSales, S.; Khakpouri, S.; Maftouh, M.; Alireza Parizadeh, S.; Mahdi Hasanian, S.; Avan, A. Current Status and Perspectives Regarding the Therapeutic Potential of Targeting EGFR Pathway by Curcumin in Lung Cancer. Curr. Pharm. Des. 2017, 23, 2002-2008. [CrossRef]

51. Wang, Z.; Lu, Y.; An, T.; Zhao, J.; Bai, H.; Duan, J.; Wu, M.; Wang, Y.; Wang, J. The Association between EGFR Gene Amplification and the Prognosis in Non-small Cell Lung Cancer: A meta-analysis. Zhongguo Fei Ai Za Zhi 2009, 12, 1247-1254.

52. Veale, D.; Kerr, N.; Gibson, G.; Kelly, P.; Harris, A.L. The relationship of quantitative epidermal growth-factor receptor expression in nonsmall cell lung-cancer to long-term survival. Br. J. Cancer 1993, 68, 162-165. [CrossRef]

53. Jiang, A.-P.; Zhou, D.-H.; Meng, X.-L.; Zhang, A.-P.; Zhang, C.; Li, X.-T.; Feng, Q. Down-regulation of epidermal growth factor receptor by curcumin-induced UBE1L in human bronchial epithelial cells. J. Nutr. Biochem. 2014, 25, 241-249. [CrossRef] [PubMed]

54. Monsalve, M.; Olmos, Y. The complex biology of FOXO. Curr. Drug Targets 2011, 12, 1322-1350. [CrossRef] [PubMed]

55. Wang, Y.; Zhou, Y.; Graves, D.T. FOXO transcription factors: Their clinical significance and regulation. BioMed Res. Int. 2014, 2014. [CrossRef]

56. Gomes, A.R.; Zhao, F.; Lam, E.W. Role and regulation of the forkhead transcription factors FOXO3a and FOXM1 in carcinogenesis and drug resistance. Chin. J. Cancer 2013, 32, 365. [CrossRef] 
57. Paik, J.-H.; Kollipara, R.; Chu, G.; Ji, H.; Xiao, Y.; Ding, Z.; Miao, L.; Tothova, Z.; Horner, J.W.; Carrasco, D.R. FoxOs are lineage-restricted redundant tumor suppressors and regulate endothelial cell homeostasis. Cell 2007, 128, 309-323. [CrossRef] [PubMed]

58. Liu, H.; Yin, J.; Wang, C.; Gu, Y.; Deng, M.; He, Z. FOXO3a mediates the cytotoxic effects of cisplatin in lung cancer cells. Anti-Cancer Drugs 2014, 25, 898-907. [CrossRef]

59. Liu, H.; Zhou, B.-H.; Qiu, X.; Wang, H.-S.; Zhang, F.; Fang, R.; Wang, X.-F.; Cai, S.-H.; Du, J.; Bu, X.-Z. T63, a new 4-arylidene curcumin analogue, induces cell cycle arrest and apoptosis through activation of the reactive oxygen species-FOXO3a pathway in lung cancer cells. Free Radic. Biol. Med. 2012, 53, 2204-2217. [CrossRef]

60. Wrana, J.L. Signaling by the TGF $\beta$ superfamily. Cold Spring Harb. Perspect. Biol. 2013, 5, a011197. [CrossRef]

61. Faler, B.J.; Macsata, R.A.; Plummer, D.; Mishra, L.; Sidawy, A.N. Transforming growth factor- $\beta$ and wound healing. Perspect. Vasc. Surg. Endovasc. Ther. 2006, 18, 55-62. [CrossRef]

62. Taylor, M.A.; Lee, Y.-H.; Schiemann, W.P. Role of TGF- $\beta$ and the tumor microenvironment during mammary tumorigenesis. Gene Expr. J. Liver Res. 2011, 15, 117-132. [CrossRef]

63. Anumanthan, G.; Halder, S.K.; Osada, H.; Takahashi, T.; Massion, P.; Carbone, D.; Datta, P. Restoration of TGF- $\beta$ signalling reduces tumorigenicity in human lung cancer cells. Br. J. Cancer 2005, 93, 1157. [CrossRef] [PubMed]

64. Haider, S.; Beauchamp, R.D.; Datta, P. Smad7 induces tumorigenicity by blocking TGF-beta-induced growth inhibition and apoptosis. FASEB J. 2004, 18, C109.

65. Samanta, D.; Gonzalez, A.L.; Nagathihalli, N.; Ye, F.; Carbone, D.P.; Datta, P.K. Smoking attenuates transforming growth factor- $\beta$-mediated tumor suppression function through downregulation of $\operatorname{Smad} 3$ in lung cancer. Cancer Prev. Res. 2012, 5, 453-463. [CrossRef] [PubMed]

66. Sakurai, R.; Li, Y.; Torday, J.S.; Rehan, V.K. Curcumin augments lung maturation, preventing neonatal lung injury by inhibiting TGF- $\beta$ signaling. Am. J. Physiol. Lung Cell. Mol. Physiol. 2011, 301, L721-L730. [CrossRef] [PubMed]

67. Gaedeke, J.; Noble, N.A.; Border, W.A. Curcumin blocks multiple sites of the TGF- $\beta$ signaling cascade in renal cells. Kidney Int. 2004, 66, 112-120. [CrossRef] [PubMed]

68. Hsu, Y.-C.; Chen, M.-J.; Yu, Y.-M.; Ko, S.-Y.; Chang, C.-C. Suppression of TGF- $\beta 1 / S M A D$ pathway and extracellular matrix production in primary keloid fibroblasts by curcuminoids: Its potential therapeutic use in the chemoprevention of keloid. Arch. Dermatol. Res. 2010, 302, 717-724. [CrossRef]

69. Song, K.; Peng, S.; Sun, Z.; Li, H.; Yang, R. Curcumin suppresses TGF- $\beta$ signaling by inhibition of TGIF degradation in scleroderma fibroblasts. Biochem. Biophys. Res. Commun. 2011, 411, 821-825. [CrossRef]

70. Datta, R.; Halder, S.K.; Zhang, B. Role of TGF- $\beta$ signaling in curcumin-mediated inhibition of tumorigenicity of human lung cancer cells. J. Cancer Res. Clin. Oncol. 2013, 139, 563-572. [CrossRef]

71. Zheng, Q.; Ye, J.; Cao, J. Translational regulator eIF2 $\alpha$ in tumor. Tumor Biol. 2014, 35, 6255-6264. [CrossRef]

72. Rosenwald, I.B.; Koifman, L.; Savas, L.; Chen, J.-J.; Woda, B.A.; Kadin, M.E. Expression of the translation initiation factors eIF-4E and eIF- $2 \alpha$ is frequently increased in neoplastic cells of Hodgkin lymphoma. Hum. Pathol. 2008, 39, 910-916. [CrossRef]

73. Salehi, Z.; Mashayekhi, F. Expression of the eukaryotic translation initiation factor 4E (eIF4E) and 4E-BP1 in esophageal cancer. Clin. Biochem. 2006, 39, 404-409. [CrossRef] [PubMed]

74. Lobo, M.V.; Martín, M.E.; Pérez, M.I.; Alonso, F.J.M.; Redondo, C.; Álvarez, M.I.; Salinas, M. Levels, phosphorylation status and cellular localization of translational factor eIF2 in gastrointestinal carcinomas. Histochem. J. 2000, 32, 139-150. [CrossRef] [PubMed]

75. Rosenwald, I.B.; Wang, S.; Savas, L.; Woda, B.; Pullman, J. Expression of translation initiation factor eIF-2 $\alpha$ is increased in benign and malignant melanocytic and colonic epithelial neoplasms. Cancer Interdiscip. Int. J. Am. Cancer Soc. 2003, 98, 1080-1088.

76. Rosenwald, I.B.; Hutzler, M.J.; Wang, S.; Savas, L.; Fraire, A.E. Expression of eukaryotic translation initiation factors $4 \mathrm{E}$ and $2 \alpha$ is increased frequently in bronchioloalveolar but not in squamous cell carcinomas of the lung. Cancer 2001, 92, 2164-2171. [CrossRef]

77. Chen, L.; Tian, G.; Shao, C.; Cobos, E.; Gao, W. Curcumin modulates eukaryotic initiation factors in human lung adenocarcinoma epithelial cells. Mol. Biol. Rep. 2010, 37, 3105-3110. [CrossRef] [PubMed]

78. Danial, N.N.; Korsmeyer, S.J. Cell death: Critical control points. Cell 2004, 116, 205-219. [CrossRef]

79. Herschman, H.R. Prostaglandin synthase 2. Biochim. Biophys. Acta (BBA) Lipids Lipid Metab. 1996, 1299, 125-140. [CrossRef] 
80. Wolff, H.; Saukkonen, K.; Anttila, S.; Karjalainen, A.; Vainio, H.; Ristimäki, A. Expression of cyclooxygenase-2 in human lung carcinoma. Cancer Res. 1998, 58, 4997-5001.

81. Hosomi, Y.; Yokose, T.; Hirose, Y.; Nakajima, R.; Nagai, K.; Nishiwaki, Y.; Ochiai, A. Increased cyclooxygenase 2 (COX-2) expression occurs frequently in precursor lesions of human adenocarcinoma of the lung. Lung Cancer 2000, 30, 73-81. [CrossRef]

82. Ismail, N.I.; Othman, I.; Abas, F.; Lajis, N.H.; Naidu, R. Mechanism of Apoptosis Induced by Curcumin in Colorectal Cancer. Int. J. Mol. Sci. 2019, 20, 2454. [CrossRef]

83. Krysan, K.; Merchant, F.H.; Zhu, L.; Dohadwala, M.; Luo, J.; Lin, Y.; HEUZE-VOURC'H, N.; Põld, M.; Seligson, D.; Chia, D. COX-2-dependent stabilization of survivin in non-small cell lung cancer. FASEB J. 2004, 18, 206-208.

84. Soslow, R.A.; Dannenberg, A.J.; Rush, D.; Woerner, B.; Khan, K.N.; Masferrer, J.; Koki, A.T. COX-2 is expressed in human pulmonary, colonic, and mammary tumors. Cancer 2000, 89, 2637-2645. [CrossRef]

85. Greenhough, A.; Smartt, H.J.; Moore, A.E.; Roberts, H.R.; Williams, A.C.; Paraskeva, C.; Kaidi, A. The COX-2/PGE 2 pathway: Key roles in the hallmarks of cancer and adaptation to the tumour microenvironment. Carcinogenesis 2009, 30, 377-386. [PubMed]

86. Sandler, A.B.; Dubinett, S.M. COX-2 inhibition and lung cancer. In Seminars in Oncology; Elsevier: Amsterdam, The Netherlands, 2004; pp. 45-52.

87. Sobolewski, C.; Cerella, C.; Dicato, M.; Ghibelli, L.; Diederich, M. The role of cyclooxygenase-2 in cell proliferation and cell death in human malignancies. Int. J. Cell Biol. 2010, 2010. [CrossRef]

88. Masferrer, J.L.; Leahy, K.M.; Koki, A.T.; Zweifel, B.S.; Settle, S.L.; Woerner, B.M.; Edwards, D.A.; Flickinger, A.G.; Moore, R.J.; Seibert, K. Antiangiogenic and antitumor activities of cyclooxygenase-2 inhibitors. Cancer Res. 2000, 60, 1306-1311.

89. Hida, T.; Yatabe, Y.; Achiwa, H.; Muramatsu, H.; Kozaki, K.-I.; Nakamura, S.; Ogawa, M.; Mitsudomi, T.; Sugiura, T.; Takahashi, T. Increased expression of cyclooxygenase 2 occurs frequently in human lung cancers, specifically in adenocarcinomas. Cancer Res. 1998, 58, 3761-3764.

90. Krysan, K.; Reckamp, K.L.; Sharma, S.; Dubinett, S.M. The potential and rationale for COX-2 inhibitors in lung cancer. Anti-Cancer Agents Med. Chem. (Former. Curr. Med. Chem. Anti-Cancer Agents) 2006, 6, 209-220. [CrossRef]

91. Lev-Ari, S.; Starr, A.; Vexler, A.; Karaush, V.; Loew, V.; Greif, J.; Fenig, E.; Aderka, D.; Ben-Yosef, R. Inhibition of pancreatic and lung adenocarcinoma cell survival by curcumin is associated with increased apoptosis, down-regulation of COX-2 and EGFR and inhibition of Erk1/2 activity. Anticancer Res. 2006, 26, 4423-4430.

92. Jobin, C.; Bradham, C.A.; Russo, M.P.; Juma, B.; Narula, A.S.; Brenner, D.A.; Sartor, R.B. Curcumin blocks cytokine-mediated NF- $\mathrm{B}$ activation and proinflammatory gene expression by inhibiting inhibitory factor I-kB kinase activity. J. Immunol. 1999, 163, 3474-3483.

93. Charalambous, M.; Maihöfner, C.; Bhambra, U.; Lightfoot, T.; Gooderham, N. Upregulation of cyclooxygenase- 2 is accompanied by increased expression of nuclear factor- $\kappa \mathrm{B}$ and $\mathrm{I} \kappa \mathrm{B}$ kinase- $\alpha$ in human colorectal cancer epithelial cells. Br. J. Cancer 2003, 88, 1598. [CrossRef]

94. Lev-Ari, S.; Starr, A.; Katzburg, S.; Berkovich, L.; Rimmon, A.; Ben-Yosef, R.; Vexler, A.; Ron, I.; Earon, G. Curcumin induces apoptosis and inhibits growth of orthotopic human non-small cell lung cancer xenografts. J. Nutr. Biochem. 2014, 25, 843-850. [CrossRef] [PubMed]

95. Yang, J.; Liu, X.; Bhalla, K.; Kim, C.N.; Ibrado, A.M.; Cai, J.; Peng, T.-I.; Jones, D.P.; Wang, X. Prevention of apoptosis by Bcl-2: Release of cytochrome c from mitochondria blocked. Science 1997, 275, 1129-1132. [CrossRef] [PubMed]

96. Adams, J.M.; Cory, S. The Bcl-2 protein family: Arbiters of cell survival. Science 1998, 281, 1322-1326. [CrossRef] [PubMed]

97. Yip, K.; Reed, J. Bcl-2 family proteins and cancer. Oncogene 2008, 27, 6398. [CrossRef] [PubMed]

98. Zhang, J.; Wang, S.; Wang, L.; Wang, R.; Chen, S.; Pan, B.; Sun, Y.; Chen, H. Prognostic value of Bcl-2 expression in patients with non-small-cell lung cancer: A meta-analysis and systemic review. Oncotargets Ther. 2015, 8, 3361. [CrossRef] [PubMed]

99. Ohsaki, Y.; Toyoshima, E.; Fujiuchi, S.; Matsui, H.; Hirata, S.; Miyokawa, N.; Kubo, Y.; Kikuchi, K. bcl-2 and p53 protein expression in non-small cell lung cancers: Correlation with survival time. Clin. Cancer Res. 1996, 2, 915-920. [PubMed] 
100. Borner, M.; Brousset, P.; Pfanner-Meyer, B.; Bacchi, M.; Vonlanthen, S.; Hotz, M.; Altermatt, H.; Schlaifer, D.; Reed, J.; Betticher, D. Expression of apoptosis regulatory proteins of the Bcl-2 family and p53 in primary resected non-small-cell lung cancer. Br. J. Cancer 1999, 79, 952. [CrossRef] [PubMed]

101. Ziegler, A.; Luedke, G.H.; Stahel, R.A.; Zangemeister-Wittke, U.; Fabbro, D.; Altmann, K.-H. Induction of apoptosis in small-cell lung cancer cells by an antisense oligodeoxynucleotide targeting the Bcl-2 coding sequence. J. Natl. Cancer Inst. 1997, 89, 1027-1036. [CrossRef]

102. Kaiser, U.; Schilli, M.; Haag, U.; Neumann, K.; Kreipe, H.; Kogan, E.; Havemann, K. Expression of bcl-2-Protein in small cell lung cancer. Lung Cancer 1996, 15, 31-40. [CrossRef]

103. Wu, S.-H.; Hang, L.-W.; Yang, J.-S.; Chen, H.-Y.; Lin, H.-Y.; Chiang, J.-H.; Lu, C.-C.; Yang, J.-L.; Lai, T.-Y.; Ko, Y.-C. Curcumin induces apoptosis in human non-small cell lung cancer NCI-H460 cells through ER stress and caspase cascade-and mitochondria-dependent pathways. Anticancer Res. 2010, 30, 2125-2133.

104. Nur-E-Kamal, A.; Gross, S.R.; Pan, Z.; Balklava, Z.; Ma, J.; Liu, L.F. Nuclear translocation of cytochrome c during apoptosis. J. Biol. Chem. 2004, 279, 24911-24914. [CrossRef] [PubMed]

105. Korsmeyer, S.J. BCL-2 gene family and the regulation of programmed cell death. Cancer Res. 1999, 59 (Suppl. 7), 1693s-1700s. [CrossRef]

106. Li, Y.; Zhang, S.; Geng, J.-X.; Hu, X.-Y. Curcumin inhibits human non-small cell lung cancer A549 cell proliferation through regulation of Bcl-2/Bax and cytochrome C. Asian Pac. J. Cancer Prev. 2013, 14, 4599-4602. [CrossRef] [PubMed]

107. Jayakumar, S.; Patwardhan, R.S.; Pal, D.; Singh, B.; Sharma, D.; Kutala, V.K.; Sandur, S.K. Mitochondrial targeted curcumin exhibits anticancer effects through disruption of mitochondrial redox and modulation of TrxR2 activity. Free Radic. Biol. Med. 2017, 113, 530-538. [CrossRef] [PubMed]

108. Xu, X.; Chen, D.; Ye, B.; Zhong, F.; Chen, G. Curcumin induces the apoptosis of non-small cell lung cancer cells through a calcium signaling pathway. Int. J. Mol. Med. 2015, 35, 1610-1616. [CrossRef] [PubMed]

109. Rong, Y.-P.; Aromolaran, A.S.; Bultynck, G.; Zhong, F.; Li, X.; McColl, K.; Matsuyama, S.; Herlitze, S.; Roderick, H.L.; Bootman, M.D. Targeting Bcl-2-IP3 receptor interaction to reverse Bcl-2's inhibition of apoptotic calcium signals. Mol. Cell 2008, 31, 255-265. [CrossRef]

110. Foyouzi-Youssefi, R.; Arnaudeau, S.; Borner, C.; Kelley, W.L.; Tschopp, J.; Lew, D.P.; Demaurex, N.; Krause, K.-H. Bcl-2 decreases the free Ca2+ concentration within the endoplasmic reticulum. Proc. Natl. Acad. Sci. USA 2000, 97, 5723-5728. [CrossRef]

111. Polivka, J., Jr.; Janku, F. Molecular targets for cancer therapy in the PI3K/AKT/mTOR pathway. Pharmacol. Ther. 2014, 142, 164-175. [CrossRef]

112. Porta, C.; Paglino, C.; Mosca, A. Targeting PI3K/Akt/mTOR signaling in cancer. Front. Oncol. $2014,4,64$. [CrossRef]

113. Vara, J.Á.F.; Casado, E.; de Castro, J.; Cejas, P.; Belda-Iniesta, C.; González-Barón, M. PI3K/Akt signalling pathway and cancer. Cancer Treat. Rev. 2004, 30, 193-204. [CrossRef]

114. Fumarola, C.; Bonelli, M.A.; Petronini, P.G.; Alfieri, R.R. Targeting PI3K/AKT/mTOR pathway in non small cell lung cancer. Biochem. Pharmacol. 2014, 90, 197-207. [CrossRef] [PubMed]

115. Scrima, M.; De Marco, C.; Fabiani, F.; Franco, R.; Pirozzi, G.; Rocco, G.; Ravo, M.; Weisz, A.; Zoppoli, P.; Ceccarelli, M. Signaling networks associated with AKT activation in non-small cell lung cancer (NSCLC): New insights on the role of phosphatydil-inositol-3 kinase. PLoS ONE 2012, 7, e30427. [CrossRef] [PubMed]

116. Papadimitrakopoulou, V. Development of PI3K/AKT/mTOR pathway inhibitors and their application in personalized therapy for non-small-cell lung cancer. J. Thorac. Oncol. 2012, 7, 1315-1326. [CrossRef] [PubMed]

117. Umemura, S.; Mimaki, S.; Makinoshima, H.; Tada, S.; Ishii, G.; Ohmatsu, H.; Niho, S.; Yoh, K.; Matsumoto, S.; Takahashi, A. Therapeutic priority of the PI3K/AKT/mTOR pathway in small cell lung cancers as revealed by a comprehensive genomic analysis. J. Thorac. Oncol. 2014, 9, 1324-1331. [CrossRef] [PubMed]

118. Liu, F.; Gao, S.; Yang, Y.; Zhao, X.; Fan, Y.; Ma, W.; Yang, D.; Yang, A.; Yu, Y. Antitumor activity of curcumin by modulation of apoptosis and autophagy in human lung cancer A549 cells through inhibiting PI3K/Akt/mTOR pathway. Oncol. Rep. 2018, 39, 1523-1531. [CrossRef] [PubMed]

119. Wang, A.; Wang, J.; Zhang, S.; Zhang, H.; Xu, Z.; Li, X. Curcumin inhibits the development of nonsmall cell lung cancer by inhibiting autophagy and apoptosis. Exp. Ther. Med. 2017, 14, 5075-5080.

120. Liu, F.; Gao, S.; Yang, Y.; Zhao, X.; Fan, Y.; Ma, W.; Yang, D.; Yang, A.; Yu, Y. Curcumin induced autophagy anticancer effects on human lung adenocarcinoma cell line A549. Oncol. Lett. 2017, 14, 2775-2782. [CrossRef] 
121. Agoulnik, I.U.; Hodgson, M.C.; Bowden, W.A.; Ittmann, M.M. INPP4B: The new kid on the PI3K block. Oncotarget 2011, 2, 321. [CrossRef]

122. Marsit, C.J.; Zheng, S.; Aldape, K.; Hinds, P.W.; Nelson, H.H.; Wiencke, J.K.; Kelsey, K.T. PTEN expression in non-small-cell lung cancer: Evaluating its relation to tumor characteristics, allelic loss, and epigenetic alteration. Hum. Pathol. 2005, 36, 768-776. [CrossRef]

123. Soria, J.-C.; Lee, H.-Y.; Lee, J.I.; Wang, L.; Issa, J.-P.; Kemp, B.L.; Liu, D.D.; Kurie, J.M.; Mao, L.; Khuri, F.R. Lack of PTEN expression in non-small cell lung cancer could be related to promoter methylation. Clin. Cancer Res. 2002, 8, 1178-1184.

124. Forgacs, E.; Biesterveld, E.J.; Sekido, Y.; Fong, K.; Muneer, S.; Wistuba, I.I.; Milchgrub, S.; Brezinschek, R.; Virmani, A.; Gazdar, A.F. Mutation analysis of the PTEN/MMAC1 gene in lung cancer. Oncogene 1998, 17, 1557. [CrossRef] [PubMed]

125. Yokomizo, A.; Tindall, D.J.; Drabkin, H.; Gemmill, R.; Franklin, W.; Yang, P.; Sugio, K.; Smith, D.I.; Liu, W. PTEN/MMAC1 mutations identified in small cell, but not in non-small cell lung cancers. Oncogene 1998, 17, 475. [CrossRef]

126. Kohno, T.; Takahashi, M.; Manda, R.; Yokota, J. Inactivation of the PTEN/MMAC1/TEP1 gene in human lung cancers. Genes Chromosomes Cancer 1998, 22, 152-156. [CrossRef]

127. Zhang, W.; Bai, W. MiR-21 suppresses the anticancer activities of curcumin by targeting PTEN gene in human non-small cell lung cancer A549 cells. Clin. Transl. Oncol. 2014, 16, 708-713. [CrossRef] [PubMed]

128. Moloney, J.N.; Cotter, T.G. ROS signalling in the biology of cancer. In Seminars in Cell E Developmental Biology; Elsevier: Amsterdam, The Netherlands, 2018; pp. 50-64.

129. Panieri, E.; Santoro, M.M. ROS homeostasis and metabolism: A dangerous liason in cancer cells. Cell Death Dis. 2016, 7, e2253. [CrossRef]

130. Yang, C.-L.; Ma, Y.-G.; Xue, Y.-X.; Liu, Y.-Y.; Xie, H.; Qiu, G.-R. Curcumin induces small cell lung cancer NCI-H446 cell apoptosis via the reactive oxygen species-mediated mitochondrial pathway and not the cell death receptor pathway. DNA Cell Biol. 2012, 31, 139-150. [CrossRef]

131. Chen, Q.; Wang, Y.; Xu, K.; Lu, G.; Ying, Z.; Wu, L.; Zhan, J.; Fang, R.; Wu, Y.; Zhou, J. Curcumin induces apoptosis in human lung adenocarcinoma A549 cells through a reactive oxygen species-dependent mitochondrial signaling pathway. Oncol. Rep. 2010, 23, 397-403. [CrossRef]

132. Yao, Q.; Lin, M.; Wang, Y.; Lai, Y.; Hu, J.; Fu, T.; Wang, L.; Lin, S.; Chen, L.; Guo, Y. Curcumin induces the apoptosis of A549 cells via oxidative stress and MAPK signaling pathways. Int. J. Mol. Med. 2015, 36, 1118-1126. [CrossRef]

133. Chen, K.; Zhang, S.; Ji, Y.; Li, J.; An, P.; Ren, H.; Liang, R.; Yang, J.; Li, Z. Baicalein inhibits the invasion and metastatic capabilities of hepatocellular carcinoma cells via down-regulation of the ERK pathway. PLoS ONE 2013, 8, e72927. [CrossRef]

134. Rane, M.J.; Song, Y.; Jin, S.; Barati, M.T.; Wu, R.; Kausar, H.; Tan, Y.; Wang, Y.; Zhou, G.; Klein, J.B. Interplay between Akt and p38 MAPK pathways in the regulation of renal tubular cell apoptosis associated with diabetic nephropathy. Am. J. Physiol. Ren. Physiol. 2009, 298, F49-F61. [CrossRef]

135. Tarapore, R.S.; Yang, Y.; Katz, J.P. Restoring KLF5 in esophageal squamous cell cancer cells activates the JNK pathway leading to apoptosis and reduced cell survival. Neoplasia (New York NY) 2013, 15, 472. [CrossRef] [PubMed]

136. Kaushik, G.; Kaushik, T.; Yadav, S.K.; Sharma, S.K.; Ranawat, P.; Khanduja, K.L.; Pathak, C.M. Curcumin Sensitizes Lung Adenocarcinoma Cells to Apoptosis Via Intracellular Redox Status Mediated Pathway. Indian. J. Exp. Bio. 2012, 50, 853-861.

137. Nagata, S.; Golstein, P. The Fas death factor. Science 1995, 267, 1449-1456. [CrossRef] [PubMed]

138. Müschen, M.; Warskulat, U.; Beckmann, M. Defining CD95 as a tumor suppressor gene. J. Mol. Med. 2000, 78, 312-325. [CrossRef] [PubMed]

139. Ashkenazi, A. Targeting the extrinsic apoptosis pathway in cancer. Cytokine Growth Factor Rev. 2008, 19, 325-331. [CrossRef] [PubMed]

140. Özören, N.; El-Deiry, W.S. Cell surface death receptor signaling in normal and cancer cells. In Seminars in Cancer Biology; Elsevier: Amsterdam, The Netherlands, 2003; pp. 135-147.

141. Lynch, D.H.; Ramsdell, F.; Alderson, M.R. Fas and FasL in the homeostatic regulation of immune responses. Immunol. Today 1995, 16, 569-574. [CrossRef] 
142. Ju, S.-T.; Panka, D.J.; Cui, H.; Ettinger, R.; Maan, E.-K.; Sherr, D.H.; Stanger, B.Z.; Marshak-Rothstein, A. Fas (CD95)/FasL interactions required for programmed cell death after T-cell activation. Nature 1995, 373, 444. [CrossRef]

143. Griffith, T.S.; Brunner, T.; Fletcher, S.M.; Green, D.R.; Ferguson, T.A. Fas ligand-induced apoptosis as a mechanism of immune privilege. Science 1995, 270, 1189-1192. [CrossRef]

144. Villa-Morales, M.; Fernandez-Piqueras, J. Targeting the Fas/FasL signaling pathway in cancer therapy. Expert Opin. Ther. Targets 2012, 16, 85-101. [CrossRef]

145. Viard-Leveugle, I.; Veyrenc, S.; French, L.E.; Brambilla, C.; Brambilla, E. Frequent loss of Fas expression and function in human lung tumours with overexpression of FasL in small cell lung carcinoma. J. Pathol. A J. Pathol. Soc. Great Br. Irel. 2003, 201, 268-277. [CrossRef]

146. Zhang, X.; Miao, X.; Sun, T.; Tan, W.; Qu, S.; Xiong, P.; Zhou, Y.; Lin, D. Functional polymorphisms in cell death pathway genes FAS and FASL contribute to risk of lung cancer. J. Med Genet. 2005, 42, 479-484. [CrossRef] [PubMed]

147. O'connell, J.; O'sullivan, G.C.; Collins, J.K.; Shanahan, F. The Fas counterattack: Fas-mediated T cell killing by colon cancer cells expressing Fas ligand. J. Exp. Med. 1996, 184, 1075-1082. [CrossRef] [PubMed]

148. Niehans, G.A.; Brunner, T.; Frizelle, S.P.; Liston, J.C.; Salerno, C.T.; Knapp, D.J.; Green, D.R.; Kratzke, R.A. Human lung carcinomas express Fas ligand. Cancer Res. 1997, 57, 1007-1012. [PubMed]

149. Bennett, M.W.; O'Connell, J.; O'Sullivan, G.C.; Brady, C.; Roche, D.; Collins, J.K.; Shanahan, F. The Fas counterattack in vivo: Apoptotic depletion of tumor-infiltrating lymphocytes associated with Fas ligand expression by human esophageal carcinoma. J. Immunol. 1998, 160, 5669-5675. [PubMed]

150. Koyama, S.; Koike, N.; Adachi, S. Fas receptor counterattack against tumor-infiltrating lymphocytes in vivo as a mechanism of immune escape in gastric carcinoma. J. Cancer Res. Clin. Oncol. 2001, 127, 20-26. [CrossRef]

151. Gupta, G.P.; Massagué, J. Cancer metastasis: Building a framework. Cell 2006, 127, 679-695. [CrossRef]

152. Sinha, S.; Yang, W. Cellular signaling for activation of Rho GTPase Cdc42. Cell. Signal. 2008, 20, 1927-1934. [CrossRef]

153. Qadir, M.I.; Parveen, A.; Ali, M. Cdc42: Role in Cancer Management. Chem. Biol. Drug Des. 2015, 86, 432-439. [CrossRef]

154. Stengel, K.; Zheng, Y. Cdc42 in oncogenic transformation, invasion, and tumorigenesis. Cell. Signal. 2011, 23, 1415-1423. [CrossRef]

155. Kodama, A.; Takaishi, K.; Nakano, K.; Nishioka, H.; Takai, Y. Involvement of Cdc42 small G protein in cell-cell adhesion, migration and morphology of MDCK cells. Oncogene 1999, 18, 3996-4006. [CrossRef]

156. Nakahara, H.; Otani, T.; Sasaki, T.; Miura, Y.; Takai, Y.; Kogo, M. Involvement of Cdc42 and Rac small G proteins in invadopodia formation of RPMI7951 cells. Genes Cells 2003, 8, 1019-1027. [CrossRef] [PubMed]

157. Arias-Romero, L.E.; Chernoff, J. Targeting Cdc42 in cancer. Expert Opin. Ther. Targets 2013, 17, $1263-1273$. [CrossRef] [PubMed]

158. Kamai, T.; Yamanishi, T.; Shirataki, H.; Takagi, K.; Asami, H.; Ito, Y.; Yoshida, K.-I. Overexpression of RhoA, Rac1, and Cdc42 GTPases Is Associated with Progression in Testicular Cancer. Clin. Cancer Res. 2004, 10, 4799-4805. [CrossRef] [PubMed]

159. Zhang, J.-Y.; Zhang, D.; Wang, E.-H. Overexpression of small GTPases directly correlates with expression of $\delta$-catenin and their coexpression predicts a poor clinical outcome in nonsmall cell lung cancer. Mol. Carcinog. 2013, 52, 338-347. [CrossRef] [PubMed]

160. Chander, H.; Truesdell, P.; Meens, J.; Craig, A.W.B. Transducer of Cdc42-dependent actin assembly promotes breast cancer invasion and metastasis. Oncogene 2012, 32, 3080. [CrossRef] [PubMed]

161. Reymond, N.; Im, J.H.; Garg, R.; Vega, F.M.; Borda d'Agua, B.; Riou, P.; Cox, S.; Valderrama, F.; Muschel, R.J.; Ridley, A.J. Cdc42 promotes transendothelial migration of cancer cells through $\beta 1$ integrin. J. Cell Biol. 2012, 199, 653-668. [CrossRef]

162. Chen, Q.-Y.; Jiao, D.-M.; Yao, Q.-H.; Yan, J.; Song, J.; Chen, F.-Y.; Lu, G.-H.; Zhou, J.-Y. Expression analysis of Cdc42 in lung cancer and modulation of its expression by curcumin in lung cancer cell lines. Int. J. Oncol. 2012, 40, 1561. [CrossRef]

163. Van Roy, F.; Berx, G. The cell-cell adhesion molecule E-cadherin. Cell. Mol. Life Sci. 2008, 65, 3756-3788. [CrossRef] 
164. Vergara, D.; Simeone, P.; Latorre, D.; Cascione, F.; Leporatti, S.; Trerotola, M.; Giudetti, A.M.; Capobianco, L.; Lunetti, P.; Rizzello, A.; et al. Proteomics analysis of E-cadherin knockdown in epithelial breast cancer cells. J. Biotechnol. 2015, 202, 3-11. [CrossRef]

165. Larue, L.; Antos, C.; Butz, S.; Huber, O.; Delmas, V.; Dominis, M.; Kemler, R. A role for cadherins in tissue formation. Development 1996, 122, 3185-3194.

166. Shiozaki, H.; Oka, H.; Inoue, M.; Tamura, S.; Monden, M. E-cadherin mediated adhesion system in cancer cells. Cancer 1996, 77, 1605-1613. [CrossRef]

167. Birchmeier, W.; Behrens, J. Cadherin expression in carcinomas: Role in the formation of cell junctions and the prevention of invasiveness. Biochim. Biophys. Acta (BBA) Rev. Cancer 1994, 1198, 11-26. [CrossRef]

168. Kowalski, P.J.; Rubin, M.A.; Kleer, C.G. E-cadherin expression in primary carcinomas of the breast and its distant metastases. Breast Cancer Res. 2003, 5, R217. [CrossRef] [PubMed]

169. Chen, H.-C.; Chu, R.Y.; Hsu, P.-N.; Hsu, P.-I.; Lu, J.-Y.; Lai, K.-H.; Tseng, H.-H.; Chou, N.-H.; Huang, M.-S.; Tseng, C.-J.; et al. Loss of E-cadherin expression correlates with poor differentiation and invasion into adjacent organs in gastric adenocarcinomas. Cancer Lett. 2003, 201, 97-106. [CrossRef]

170. Takeichi, M. Cadherins in cancer: Implications for invasion and metastasis. Curr. Opin. Cell Biol. 1993, 5, 806-811. [CrossRef]

171. Onder, T.T.; Gupta, P.B.; Mani, S.A.; Yang, J.; Lander, E.S.; Weinberg, R.A. Loss of E-Cadherin Promotes Metastasis via Multiple Downstream Transcriptional Pathways. Cancer Res. 2008, 68, 3645-3654. [CrossRef]

172. Canel, M.; Serrels, A.; Frame, M.C.; Brunton, V.G. E-cadherin-integrin crosstalk in cancer invasion and metastasis. J. Cell Sci. 2013, 126, 393-401. [CrossRef]

173. Böhm, M.; Totzeck, B.; Birchmeier, W.; Wieland, I. Differences of E-cadherin expression levels and patterns in primary and metastatic human lung cancer. Clin. Exp. Metastasis 1994, 12, 55-62. [CrossRef]

174. Chen, H.-W.; Lee, J.-Y.; Huang, J.-Y.; Wang, C.-C.; Chen, W.-J.; Su, S.-F.; Huang, C.-W.; Ho, C.-C.; Chen, J.J.W.; Tsai, M.-F; ; et al. Curcumin Inhibits Lung Cancer Cell Invasion and Metastasis through the Tumor Suppressor HLJ1. Cancer Res. 2008, 68, 7428-7438. [CrossRef]

175. Nagase, H.; Visse, R.; Murphy, G. Structure and function of matrix metalloproteinases and TIMPs. Cardiovasc. Res. 2006, 69, 562-573. [CrossRef]

176. Shay, G.; Lynch, C.C.; Fingleton, B. Moving targets: Emerging roles for MMPs in cancer progression and metastasis. Matrix Biol. 2015, 44-46, 200-206. [CrossRef] [PubMed]

177. Stetler-Stevenson, W.G. The Role of Matrix Metalloproteinases in Tumor Invasion, Metastasis, and Angiogenesis. Surg. Oncol. Clin. 2001, 10, 383-392. [CrossRef]

178. Deryugina, E.I.; Quigley, J.P. Matrix metalloproteinases and tumor metastasis. Cancer Metastasis Rev. 2006, 25, 9-34. [CrossRef] [PubMed]

179. Hung, W.-C.; Tseng, W.-L.; Shiea, J.; Chang, H.-C. Skp2 overexpression increases the expression of MMP-2 and MMP-9 and invasion of lung cancer cells. Cancer Lett. 2010, 288, 156-161. [CrossRef] [PubMed]

180. Kodate, M.; Kasai, T.; Hashirnoto, H.; Yasumoto, K.; Iwata, Y.; Manabe, H. Expression of matrix metalloproteinase (gelatinase) in T1 adenocarcinoma of the lung. Pathol. Int. 1997, 47, 461-469. [CrossRef] [PubMed]

181. Swarnakar, S.; Ganguly, K.; Kundu, P.; Banerjee, A.; Maity, P.; Sharma, A.V. Curcumin regulates expression and activity of matrix metalloproteinases 9 and 2 during prevention and healing of indomethacin-induced gastric ulcer. J. Biol. Chem. 2005, 280, 9409-9415. [CrossRef]

182. Chen, Q.; Gao, Q.; Chen, K.; Wang, Y.; Chen, L.; Li, X. Curcumin suppresses migration and invasion of human endometrial carcinoma cells. Oncol. Lett. 2015, 10, 1297-1302. [CrossRef]

183. Lakka, S.S.; Jasti, S.L.; Gondi, C.; Boyd, D.; Chandrasekar, N.; Dinh, D.H.; Olivero, W.C.; Gujrati, M.; Rao, J.S. Downregulation of MMP-9 in ERK-mutated stable transfectants inhibits glioma invasion in vitro. Oncogene 2002, 21, 5601. [CrossRef]

184. Mitra, A.; Chakrabarti, J.; Banerji, A.; Chatterjee, A.; Das, B. Curcumin, a potential inhibitor of MMP-2 in human laryngeal squamous carcinoma cells HEp2. J. Environ. Pathol. Toxicol. Oncol. 2006, 25. [CrossRef]

185. Lin, S.-S.; Lai, K.-C.; Hsu, S.-C.; Yang, J.-S.; Kuo, C.-L.; Lin, J.-P.; Ma, Y.-S.; Wu, C.-C.; Chung, J.-G. Curcumin inhibits the migration and invasion of human A549 lung cancer cells through the inhibition of matrix metalloproteinase-2 and -9 and Vascular Endothelial Growth Factor (VEGF). Cancer Lett. 2009, 285, 127-133. [CrossRef] 
186. Xiao, L.-J.; Lin, P.; Lin, F.; Liu, X.; Qin, W.; Zou, H.-F.; Guo, L.; Liu, W.; Wang, S.-J.; Yu, X.-G. ADAM17 targets MMP-2 and MMP-9 via EGFR-MEK-ERK pathway activation to promote prostate cancer cell invasion. Int. J. Oncol. 2012, 40, 1714-1724. [PubMed]

187. Rhee, J.W.; Lee, K.-W.; Sohn, W.-J.; Lee, Y.; Jeon, O.-H.; Kwon, H.-J.; Kim, D.-S. Regulation of matrix metalloproteinase-9 gene expression and cell migration by NF- $\mathrm{kB}$ in response to CpG-oligodeoxynucleotides in RAW 264.7 cells. Mol. Immunol. 2007, 44, 1393-1400. [CrossRef] [PubMed]

188. Bergers, G.; Brekken, R.; McMahon, G.; Vu, T.H.; Itoh, T.; Tamaki, K.; Tanzawa, K.; Thorpe, P.; Itohara, S.; Werb, Z. Matrix metalloproteinase-9 triggers the angiogenic switch during carcinogenesis. Nat. Cell Biol. 2000, 2, 737. [CrossRef] [PubMed]

189. Gialeli, C.; Theocharis, A.D.; Karamanos, N.K. Roles of matrix metalloproteinases in cancer progression and their pharmacological targeting. FEBS J. 2011, 278, 16-27. [CrossRef] [PubMed]

190. Chen, Q.-Y.; Zheng, Y.; Jiao, D.-M.; Chen, F.-Y.; Hu, H.-Z.; Wu, Y.-Q.; Song, J.; Yan, J.; Wu, L.-J.; Lv, G.-Y. Curcumin inhibits lung cancer cell migration and invasion through Rac1-dependent signaling pathway. J. Nutr. Biochem. 2014, 25, 177-185. [CrossRef] [PubMed]

191. Raftopoulou, M.; Hall, A. Cell migration: Rho GTPases lead the way. Dev. Biol. 2004, 265, 23-32. [CrossRef]

192. Fan, Z.; Duan, X.; Cai, H.; Wang, L.; Li, M.; Qu, J.; Li, W.; Wang, Y.; Wang, J. Curcumin inhibits the invasion of lung cancer cells by modulating the PKC $\alpha /$ Nox-2/ROS/ATF-2/MMP-9 signaling pathway. Oncol. Rep. 2015, 34, 691-698. [CrossRef]

193. Koerner, A.; Kratzsch, J.; Kiess, W. Adipocytokines: Leptin-The classical, resistin-The controversical, adiponectin-The promising, and more to come. Best Pract. Res. Clin. Endocrinol. Metab. 2005, 19, 525-546. [CrossRef]

194. Dalamaga, M.; Diakopoulos, K.N.; Mantzoros, C.S. The role of adiponectin in cancer: A review of current evidence. Endocr. Rev. 2012, 33, 547-594. [CrossRef]

195. Ishikawa, M.; Kitayama, J.; Kazama, S.; Hiramatsu, T.; Hatano, K.; Nagawa, H. Plasma adiponectin and gastric cancer. Clin. Cancer Res. 2005, 11, 466-472.

196. Goktas, S.; Yilmaz, M.I.; Caglar, K.; Sonmez, A.; Kilic, S.; Bedir, S. Prostate cancer and adiponectin. Urology 2005, 65, 1168-1172. [CrossRef] [PubMed]

197. Arisan, E.D.; Arisan, S.; Atis, G.; Palavan-Unsal, N.; Ergenekon, E. Serum adipocytokine levels in prostate cancer patients. Urol. Int. 2009, 82, 203-208. [CrossRef] [PubMed]

198. Ntikoudi, E.; Kiagia, M.; Boura, P.; Syrigos, K. Hormones of adipose tissue and their biologic role in lung cancer. Cancer Treat. Rev. 2014, 40, 22-30. [CrossRef] [PubMed]

199. Tsai, J.-R.; Liu, P.-L.; Chen, Y.-H.; Chou, S.-H.; Cheng, Y.-J.; Hwang, J.-J.; Chong, I.-W. Curcumin inhibits non-small cell lung cancer cells metastasis through the Adiponectin/NF-kb/MMPs signaling pathway. PLoS ONE 2015, 10, e0144462. [CrossRef]

200. Sharma, S.; Kelly, T.K.; Jones, P.A. Epigenetics in cancer. Carcinogenesis 2010, 31, 27-36. [CrossRef]

201. Jones, P.A. Overview of cancer epigenetics. In Seminars in Hematology; Elsevier: Amsterdam, The Netherlands, 2005; pp. S3-S8.

202. Sawan, C.; Vaissière, T.; Murr, R.; Herceg, Z. Epigenetic drivers and genetic passengers on the road to cancer. Mutat. Res. Fundam. Mol. Mech. Mutagenesis 2008, 642, 1-13. [CrossRef]

203. Fu, S.; Kurzrock, R. Development of curcumin as an epigenetic agent. Cancer 2010, 116, 4670-4676. [CrossRef]

204. Teiten, M.H.; Dicato, M.; Diederich, M. Curcumin as a regulator of epigenetic events. Mol. Nutr. Food Res. 2013, 57, 1619-1629. [CrossRef]

205. Das, P.M.; Singal, R. DNA methylation and cancer. J. Clin. Oncol. 2004, 22, 4632-4642. [CrossRef]

206. Ehrlich, M. DNA hypomethylation in cancer cells. Epigenomics 2009, 1, 239-259. [CrossRef]

207. Esteller, M. Epigenetics in cancer. N. Engl. J. Med. 2008, 358, 1148-1159. [CrossRef] [PubMed]

208. Herman, J.G.; Baylin, S.B. Gene silencing in cancer in association with promoter hypermethylation. N. Engl. J. Med. 2003, 349, 2042-2054. [CrossRef] [PubMed]

209. Liu, Z.; Xie, Z.; Jones, W.; Pavlovicz, R.E.; Liu, S.; Yu, J.; Li, P.-k.; Lin, J.; Fuchs, J.R.; Marcucci, G. Curcumin is a potent DNA hypomethylation agent. Bioorg. Med. Chem. Lett. 2009, 19, 706-709. [CrossRef] [PubMed]

210. Parashar, G.; Parashar, N.C.; Capalash, N. Curcumin causes promoter hypomethylation and increased expression of FANCF gene in SiHa cell line. Mol. Cell. Biochem. 2012, 365, 29-35. [CrossRef] [PubMed] 
211. Jha, A.; Nikbakht, M.; Parashar, G.; Shrivastava, A.; Capalash, N.; Kaur, J. Reversal of hypermethylation and reactivation of the RARß2 gene by natural compounds in cervical cancer cell lines. Folia Biol. (Praha) 2010, 56, 195-200. [PubMed]

212. Abusnina, A.; Keravis, T.; Yougbaré, I.; Bronner, C.; Lugnier, C. Anti-proliferative effect of curcumin on melanoma cells is mediated by PDE1A inhibition that regulates the epigenetic integrator UHRF1. Mol. Nutr. Food Res. 2011, 55, 1677-1689. [CrossRef]

213. Du, L.; Xie, Z.; Wu, L.-C.; Chiu, M.; Lin, J.; Chan, K.K.; Liu, S.; Liu, Z. Reactivation of RASSF1A in breast cancer cells by curcumin. Nutr. Cancer 2012, 64, 1228-1235. [CrossRef]

214. Shu, L.; Khor, T.O.; Lee, J.-H.; Boyanapalli, S.S.; Huang, Y.; Wu, T.-Y.; Saw, C.L.-L.; Cheung, K.-L.; Kong, A.-N.T. Epigenetic $\mathrm{CPG}$ demethylation of the promoter and reactivation of the expression of Neurog1 by curcumin in prostate LNCaP cells. AAPS J. 2011, 13, 606-614. [CrossRef]

215. Boyanapalli, S.S.; Kong, A.-N.T. "Curcumin, the king of spices": Epigenetic regulatory mechanisms in the prevention of cancer, neurological, and inflammatory diseases. Curr. Pharmacol. Rep. 2015, 1, 129-139. [CrossRef]

216. Momparler, R.L.; Bovenzi, V. DNA methylation and cancer. J. Cell. Physiol. 2000, 183, 145-154. [CrossRef]

217. Liu, Y.-L.; Yang, H.-P.; Gong, L.; Tang, C.-L.; Wang, H.-J. Hypomethylation effects of curcumin, demethoxycurcumin and bisdemethoxycurcumin on WIF-1 promoter in non-small cell lung cancer cell lines. Mol. Med. Rep. 2011, 4, 675-679. [PubMed]

218. Kouzarides, T. Chromatin modifications and their function. Cell 2007, 128, 693-705. [CrossRef] [PubMed]

219. Sawan, C.; Herceg, Z. Histone modifications and cancer. In Advances in Genetics; Elsevier: Amsterdam, The Netherlands, 2010; Volume 70, pp. 57-85.

220. Bannister, A.J.; Kouzarides, T. Regulation of chromatin by histone modifications. Cell Res. 2011, $21,381$. [CrossRef] [PubMed]

221. Strahl, B.D.; Allis, C.D. The language of covalent histone modifications. Nature 2000, 403, 41. [CrossRef] [PubMed]

222. Yasui, W.; Oue, N.; Ono, S.; Mitani, Y.; Ito, R.; Nakayama, H. Histone acetylation and gastrointestinal carcinogenesis. Ann. N. Y. Acad. Sci. 2003, 983, 220-231. [CrossRef] [PubMed]

223. Wang, C.; Fu, M.; Mani, S.; Wadler, S.; Senderowicz, A.M.; Pestell, R.G. Histone acetylation and the cell-cycle in cancer. Front Biosci. 2001, 6, 610-629. [CrossRef]

224. Archer, S.Y.; Hodin, R.A. Histone acetylation and cancer. Curr. Opin. Genet. Dev. 1999, 9, 171-174. [CrossRef]

225. Kang, S.-K.; Cha, S.-H.; Jeon, H.-G. Curcumin-induced histone hypoacetylation enhances caspase-3-dependent glioma cell death and neurogenesis of neural progenitor cells. Stem Cells Dev. 2006, 15, 165-174. [CrossRef]

226. Chen, Y.; Shu, W.; Chen, W.; Wu, Q.; Liu, H.; Cui, G. Curcumin, both histone deacetylase and p300/CBP-specific inhibitor, represses the activity of nuclear factor kappa B and Notch 1 in Raji cells. Basic Clin. Pharmacol. Toxicol. 2007, 101, 427-433. [CrossRef]

227. Marcu, M.G.; Jung, Y.-J.; Lee, S.; Chung, E.-J.; Lee, M.-J.; Trepel, J.; Neckers, L. Curcumin is an inhibitor of p300 histone acetylatransferase. Med. Chem. 2006, 2, 169-174.

228. Bushati, N.; Cohen, S.M. MicroRNA Functions. Annu. Rev. Cell Dev. Biol. 2007, 23, 175-205. [CrossRef] [PubMed]

229. Ha, M.; Kim, V.N. Regulation of microRNA biogenesis. Nat. Rev. Mol. Cell Biol. 2014, 15, 509. [CrossRef] [PubMed]

230. Lu, J.; Getz, G.; Miska, E.A.; Alvarez-Saavedra, E.; Lamb, J.; Peck, D.; Sweet-Cordero, A.; Ebert, B.L.; Mak, R.H.; Ferrando, A.A. MicroRNA expression profiles classify human cancers. Nature 2005, 435, 834. [CrossRef] [PubMed]

231. Calin, G.A.; Croce, C.M. MicroRNA signatures in human cancers. Nat. Rev. Cancer 2006, 6, 857. [CrossRef] [PubMed]

232. Fortunato, O.; Boeri, M.; Verri, C.; Moro, M.; Sozzi, G. Therapeutic use of microRNAs in lung cancer. BioMed Res. Int. 2014, 2014. [CrossRef] [PubMed]

233. Inamura, K.; Ishikawa, Y. MicroRNA in lung cancer: Novel biomarkers and potential tools for treatment. J. Clin. Med. 2016, 5, 36. [CrossRef]

234. Johnson, C.D.; Esquela-Kerscher, A.; Stefani, G.; Byrom, M.; Kelnar, K.; Ovcharenko, D.; Wilson, M.; Wang, X.; Shelton, J.; Shingara, J. The let-7 microRNA represses cell proliferation pathways in human cells. Cancer Res. 2007, 67, 7713-7722. [CrossRef] 
235. Esquela-Kerscher, A.; Trang, P.; Wiggins, J.F.; Patrawala, L.; Cheng, A.; Ford, L.; Weidhaas, J.B.; Brown, D.; Bader, A.G.; Slack, F.J. The let-7 microRNA reduces tumor growth in mouse models of lung cancer. Cell Cycle 2008, 7, 759-764. [CrossRef]

236. Garofalo, M.; Jeon, Y.-J.; Nuovo, G.J.; Middleton, J.; Secchiero, P.; Joshi, P.; Alder, H.; Nazaryan, N.; Di Leva, G.; Romano, G. MiR-34a/c-dependent PDGFR- $\alpha / \beta$ downregulation inhibits tumorigenesis and enhances TRAIL-induced apoptosis in lung cancer. PLoS ONE 2013, 8, e67581. [CrossRef]

237. Fabbri, M.; Garzon, R.; Cimmino, A.; Liu, Z.; Zanesi, N.; Callegari, E.; Liu, S.; Alder, H.; Costinean, S.; Fernandez-Cymering, C. MicroRNA-29 family reverts aberrant methylation in lung cancer by targeting DNA methyltransferases 3A and 3B. Proc. Natl. Acad. Sci. USA 2007, 104, 15805-15810. [CrossRef]

238. Bommer, G.T.; Gerin, I.; Feng, Y.; Kaczorowski, A.J.; Kuick, R.; Love, R.E.; Zhai, Y.; Giordano, T.J.; Qin, Z.S.; Moore, B.B. p53-mediated activation of miRNA34 candidate tumor-suppressor genes. Curr. Biol. 2007, 17, 1298-1307. [CrossRef] [PubMed]

239. Lelli, D.; Pedone, C.; Majeed, M.; Sahebkar, A. Curcumin and lung cancer: The role of microRNAs. Curr. Pharm. Des. 2017, 23, 3440-3444. [CrossRef] [PubMed]

240. Momtazi, A.A.; Shahabipour, F.; Khatibi, S.; Johnston, T.P.; Pirro, M.; Sahebkar, A. Curcumin as a MicroRNA regulator in cancer: A review. In Reviews of Physiology, Biochemistry and Pharmacology; Springer: New York, NY, USA, 2016; Volume 171, pp. 1-38.

241. Sun, M.; Estrov, Z.; Ji, Y.; Coombes, K.R.; Harris, D.H.; Kurzrock, R. Curcumin (diferuloylmethane) alters the expression profiles of microRNAs in human pancreatic cancer cells. Mol. Cancer Ther. 2008, 7, 464-473. [CrossRef] [PubMed]

242. Mirzaei, H.; Masoudifar, A.; Sahebkar, A.; Zare, N.; Sadri Nahand, J.; Rashidi, B.; Mehrabian, E.; Mohammadi, M.; Mirzaei, H.R.; Jaafari, M.R. MicroRNA: A novel target of curcumin in cancer therapy. J. Cell. Physiol. 2018, 233, 3004-3015. [CrossRef]

243. Zhang, J.; Du, Y.; Wu, C.; Ren, X.; Ti, X.; Shi, J.; Zhao, F.; Yin, H. Curcumin promotes apoptosis in human lung adenocarcinoma cells through miR-186* signaling pathway. Oncol. Rep. 2010, 24, 1217-1223. [CrossRef]

244. Tang, N.; Zhang, J.; Du, Y. Curcumin promoted the apoptosis of cisplain-resistant human lung carcinoma cells A549/DDP through down-regulating miR-186*. Zhongguo Fei Ai Za Zhi= Chin. J. Lung Cancer 2010, 13, 301-306.

245. Ye, M.; Zhang, J.; Zhang, J.; Miao, Q.; Yao, L.; Zhang, J. Curcumin promotes apoptosis by activating the p53-miR-192-5p/215-XIAP pathway in non-small cell lung cancer. Cancer Lett. 2015, 357, 196-205. [CrossRef]

246. Jin, H.; Qiao, F.; Wang, Y.; Xu, Y.; Shang, Y. Curcumin inhibits cell proliferation and induces apoptosis of human non-small cell lung cancer cells through the upregulation of miR-192-5p and suppression of PI3K/Akt signaling pathway. Oncol. Rep. 2015, 34, 2782-2789. [CrossRef]

247. Ahmad, A.; Sayed, A.; Ginnebaugh, K.R.; Sharma, V.; Suri, A.; Saraph, A.; Padhye, S.; Sarkar, F.H. Molecular docking and inhibition of matrix metalloproteinase-2 by novel difluorinatedbenzylidene curcumin analog. Am. J. Transl. Res. 2015, 7, 298.

248. Wu, G.-Q.; Chai, K.-Q.; Zhu, X.-M.; Jiang, H.; Wang, X.; Xue, Q.; Zheng, A.-H.; Zhou, H.-Y.; Chen, Y.; Chen, X.-C. Anti-cancer effects of curcumin on lung cancer through the inhibition of EZH2 and NOTCH1. Oncotarget 2016, 7, 26535. [CrossRef]

249. Liu, W.-L.; Chang, J.-M.; Chong, I.-W.; Hung, Y.-L.; Chen, Y.-H.; Huang, W.-T.; Kuo, H.-F.; Hsieh, C.-C.; Liu, P.-L. Curcumin Inhibits LIN-28A through the Activation of miRNA-98 in the Lung Cancer Cell Line A549. Molecules 2017, 22, 929. [CrossRef] [PubMed]

250. Devassy, J.G.; Nwachukwu, I.D.; Jones, P.J. Curcumin and cancer: Barriers to obtaining a health claim. Nutr. Rev. 2015, 73, 155-165. [CrossRef] [PubMed]

251. Anand, P.; Kunnumakkara, A.B.; Newman, R.A.; Aggarwal, B.B. Bioavailability of Curcumin: Problems and Promises. Mol. Pharm. 2007, 4, 807-818. [CrossRef] [PubMed]

252. Ireson, C.R.; Jones, D.J.L.; Orr, S.; Coughtrie, M.W.H.; Boocock, D.J.; Williams, M.L.; Farmer, P.B.; Steward, W.P.; Gescher, A.J. Metabolism of the Cancer Chemopreventive Agent Curcumin in Human and Rat Intestine. Cancer Epidemiol. Biomark. AMP Prev. 2002, 11, 105-111.

253. Pan, M.-H.; Huang, T.-M.; Lin, J.-K. Biotransformation of Curcumin through Reduction and Glucuronidation in Mice. Drug Metab. Dispos. 1999, 27, 486-494.

254. Somparn, P.; Phisalaphong, C.; Nakornchai, S.; Unchern, S.; Morales, N.P. Comparative antioxidant activities of curcumin and its demethoxy and hydrogenated derivatives. Biol. Pharm. Bull. 2007, 30, 74-78. [CrossRef] 
255. Sandur, S.K.; Pandey, M.K.; Sung, B.; Ahn, K.S.; Murakami, A.; Sethi, G.; Limtrakul, P.; Badmaev, V.; Aggarwal, B.B. Curcumin, demethoxycurcumin, bisdemethoxycurcumin, tetrahydrocurcumin and turmerones differentially regulate anti-inflammatory and anti-proliferative responses through a ROS-independent mechanism. Carcinogenesis 2007, 28, 1765-1773. [CrossRef]

256. Heger, M.; van Golen, R.F.; Broekgaarden, M.; Michel, M.C. The Molecular Basis for the Pharmacokinetics and Pharmacodynamics of Curcumin and Its Metabolites in Relation to Cancer. Pharmacol. Rev. 2014, 66, 222-307. [CrossRef]

257. Pal, A.; Sung, B.; Prasad, B.A.B.; Schuber, P.T., Jr.; Prasad, S.; Aggarwal, B.B.; Bornmann, W.G. Curcumin glucuronides: Assessing the proliferative activity against human cell lines. Bioorg. Med. Chem. 2014, 22, 435-439. [CrossRef]

258. Ireson, C.; Orr, S.; Jones, D.J.; Verschoyle, R.; Lim, C.-K.; Luo, J.-L.; Howells, L.; Plummer, S.; Jukes, R.; Williams, M. Characterization of metabolites of the chemopreventive agent curcumin in human and rat hepatocytes and in the rat in vivo, and evaluation of their ability to inhibit phorbol ester-induced prostaglandin E2 production. Cancer Res. 2001, 61, 1058-1064.

259. Prasad, S.; Tyagi, A.K.; Aggarwal, B.B. Recent developments in delivery, bioavailability, absorption and metabolism of curcumin: The golden pigment from golden spice. Cancer Res. Treat. 2014, 46, 2-18. [CrossRef]

260. Shoba, G.; Joy, D.; Joseph, T.; Majeed, M.; Rajendran, R.; Srinivas, P.S.S.R. Influence of Piperine on the Pharmacokinetics of Curcumin in Animals and Human Volunteers. Planta Med. 1998, 64, 353-356. [CrossRef] [PubMed]

261. Mohan Yallapu, M.; Ray Dobberpuhl, M.; Michele Maher, D.; Jaggi, M.; Chand Chauhan, S. Design of Curcumin loaded Cellulose Nanoparticles for Prostate Cancer. Curr. Drug Metab. 2012, 13, 120-128. [CrossRef] [PubMed]

262. Shaikh, J.; Ankola, D.D.; Beniwal, V.; Singh, D.; Kumar, M.N.V.R. Nanoparticle encapsulation improves oral bioavailability of curcumin by at least 9 -fold when compared to curcumin administered with piperine as absorption enhancer. Eur. J. Pharm. Sci. 2009, 37, 223-230. [CrossRef]

263. Bisht, S.; Mizuma, M.; Feldmann, G.; Ottenhof, N.A.; Hong, S.-M.; Pramanik, D.; Chenna, V.; Karikari, C.; Sharma, R.; Goggins, M.G.; et al. Systemic Administration of Polymeric Nanoparticle-Encapsulated Curcumin (NanoCurc) Blocks Tumor Growth and Metastases in Preclinical Models of Pancreatic Cancer. Mol. Cancer Ther. 2010, 9, 2255-2264. [CrossRef]

264. Lin, Y.-L.; Liu, Y.-K.; Tsai, N.-M.; Hsieh, J.-H.; Chen, C.-H.; Lin, C.-M.; Liao, K.-W. A Lipo-PEG-PEI complex for encapsulating curcumin that enhances its antitumor effects on curcumin-sensitive and curcumin-resistance cells. Nanomed. Nanotechnol. Biol. Med. 2012, 8, 318-327. [CrossRef]

265. Ma, Z.; Shayeganpour, A.; Brocks, D.R.; Lavasanifar, A.; Samuel, J. High-performance liquid chromatography analysis of curcumin in rat plasma: Application to pharmacokinetics of polymeric micellar formulation of curcumin. Biomed. Chromatogr. 2007, 21, 546-552. [CrossRef]

266. Liu, A.; Lou, H.; Zhao, L.; Fan, P. Validated LC/MS/MS assay for curcumin and tetrahydrocurcumin in rat plasma and application to pharmacokinetic study of phospholipid complex of curcumin. J. Pharm. Biomed. Anal. 2006, 40, 720-727. [CrossRef]

267. Mosley, C.A.; Liotta, D.C.; Snyder, J.P. Highly active anticancer curcumin analogues. In The Molecular Targets and Therapeutic Uses of Curcumin in Health and Disease; Aggarwal, B.B., Surh, Y.-J., Shishodia, S., Eds.; Springer: Boston, MA, USA, 2007; pp. 77-103.

268. Mehta, H.J.; Patel, V.; Sadikot, R.T. Curcumin and lung cancer-A review. Target. Oncol. 2014, 9, $295-310$. [CrossRef]

269. López-Lázaro, M. Anticancer and carcinogenic properties of curcumin: Considerations for its clinical development as a cancer chemopreventive and chemotherapeutic agent. Mol. Nutr. Food Res. 2008, 52, S103-S127. [CrossRef]

270. National Toxicology Program. NTP Toxicology and Carcinogenesis Studies of Turmeric Oleoresin (CAS No. 8024-37-1) (Major Component 79\%-85\% Curcumin, CAS No. 458-37-7) in F344/N Rats and B6C3F1 Mice (Feed Studies). Natl. Toxicol. Program Tech. Rep. Ser. 1993, 427, 1-275.

271. Somasundaram, S.; Edmund, N.A.; Moore, D.T.; Small, G.W.; Shi, Y.Y.; Orlowski, R.Z. Dietary Curcumin Inhibits Chemotherapy-induced Apoptosis in Models of Human Breast Cancer. Cancer Res. 2002, 62, 3868-3875. [PubMed] 
272. López-Lázaro, M. Dual role of hydrogen peroxide in cancer: Possible relevance to cancer chemoprevention and therapy. Cancer Lett. 2007, 252, 1-8. [CrossRef] [PubMed]

273. Fang, J.; Lu, J.; Holmgren, A. Thioredoxin reductase is irreversibly modified by curcumin: A novel molecular mechanism for its anticancer activity. J. Biol. Chem. 2005, 280, 25284-25290. [CrossRef] [PubMed]

274. Syng-ai, C.; Kumari, A.L.; Khar, A. Effect of curcumin on normal and tumor cells: Role of glutathione and bcl-2. Mol. Cancer Ther. 2004, 3, 1101-1108.

275. Cao, J.; Jia, L.; Zhou, H.-M.; Liu, Y.; Zhong, L.-F. Mitochondrial and Nuclear DNA Damage Induced by Curcumin in Human Hepatoma G2 Cells. Toxicol. Sci. 2006, 91, 476-483. [CrossRef]

276. Sharma, R.A.; Euden, S.A.; Platton, S.L.; Cooke, D.N.; Shafayat, A.; Hewitt, H.R.; Marczylo, T.H.; Morgan, B.; Hemingway, D.; Plummer, S.M.; et al. Phase I Clinical Trial of Oral Curcumin: Biomarkers of Systemic Activity and Compliance. Clin. Cancer Res. 2004, 10, 6847-6854. [CrossRef]

277. Kanai, M.; Yoshimura, K.; Asada, M.; Imaizumi, A.; Suzuki, C.; Matsumoto, S.; Nishimura, T.; Mori, Y.; Masui, T.; Kawaguchi, Y. A phase I/II study of gemcitabine-based chemotherapy plus curcumin for patients with gemcitabine-resistant pancreatic cancer. Cancer Chemother. Pharmacol. 2011, 68, 157-164. [CrossRef]

278. Pavan, A.R.; Silva, G.D.; Jornada, D.H.; Chiba, D.E.; Fernandes, G.F.; Man Chin, C.; Dos Santos, J.L. Unraveling the Anticancer Effect of Curcumin and Resveratrol. Nutrients 2016, 8, 628. [CrossRef]

279. Shehzad, A.; Wahid, F.; Lee, Y.S. Curcumin in cancer chemoprevention: Molecular targets, pharmacokinetics, bioavailability, and clinical trials. Arch. Der Pharm. 2010, 343, 489-499. [CrossRef]

(C) 2019 by the authors. Licensee MDPI, Basel, Switzerland. This article is an open access article distributed under the terms and conditions of the Creative Commons Attribution (CC BY) license (http://creativecommons.org/licenses/by/4.0/). 